\title{
34. A GEOPHYSICAL STUDY OF THE ROSS SEA, ANTARCTICA ${ }^{1}$
}

\author{
Dennis E. Hayes, ${ }^{2}$ Lamont Doherty Geological Observatory of Columbia University, Palisades, New York \\ and \\ F.J. Davey, Geophysics Division, D.S.I.R., P.O. Box 8005, Wellington, New Zealand
}

\begin{abstract}
New bathymetric, gravity, and magnetic data in the Ross Sea are presented. The bathymetric data show that the entire Ross Sea continental shelf has a mean depth of about 500 meters with the eastern half systematically deeper than the western half. Subdued ridges and valleys characterize the relief of the shelf and trend roughly northsouth east of the $180^{\circ}$ meridian and northeast-southwest west of it. These features appear to be primarily the result of erosion by past movement of a partially grounded Ross Ice Shelf. The continental slope is tectonically complex especially to the west of Iselin Bank. The most dramatic geophysical feature of the Ross Sea shelf is the linear positive gravity anomaly belt trending north-south across the western Ross Sea. This positive gravity belt is about $700 \mathrm{~km}$ long, 50 to $100 \mathrm{~km}$ wide, and has an amplitude of up to $80 \mathrm{mgal}$. We interpret it as marking the position of an ancient rift, probably active during the separation of Australia and New Zealand from Australia. The major sedimentary basin underlying the eastern Ross Sea is not marked by any significant local or regional gravity anomalies and probably contains highly compacted sediments. Large magnetic anomalies over the Ross Sea are few and these are local in extent.
\end{abstract}

\section{INTRODUCTION}

This paper presents bathymetric, gravity, and magnetic data obtained during four cruises of USNS Eltanin to the Ross Sea, Antarctica. The location of the area investigated and the track chart are shown in Figure 1. The seismic data recorded during these cruises have been interpreted by Houtz and Davey (1973), and their results are used in this paper. A navy satellite navigation system was in use for all the cruises and the navigational uncertainty in the geophysical measurements should seldom exceed $0.5 \mathrm{~km}$.

The Antarctic continent has been classified as two subcontinents, East and West Antarctica, on the basis of topography and geology (Adie, 1962). The Ross Sea lies at the northern end of the junction between the two subcontinents near the $180^{\circ}$ meridian and is delineated by the Transantarctic Mountains of Victoria Land to the west, Marie Byrd Land to the east, and the Ross Ice Shelf to the south (Figure 1). The Transantarctic Mountains have been interpreted both as a monoclinal fold (King, 1965; Harrington et al., 1967) and as an upfaulted block (David and Priestley, 1914; Gunn, 1963; Robinson, 1964). The mountains are formed of folded

\footnotetext{
'Lamont-Doherty Contribution No. 2151.

${ }^{2}$ also Department of Geological Sciences, Columbia University, New York.
}

Precambrian and Paleozoic metamorphics which have been intruded by lower Paleozoic acidic intrusives and overlain by flat-lying Devonian to Jurassic sediments (Beacon group) and Jurassic dolerite sills (Ferrar group). In contrast, the geology of western Marie Byrd Land consists of highly folded metamorphic rocks of Cretaceous or older age intruded by granite batholiths of mid-Cretaceous age (Wade and Wilbanks, 1972). Cenozoic volcanic rocks are found further east in Marie Byrd Land.

The Ross Sea continental shelf, hereafter called the Ross Sea shelf, Ross Ice Shelf, and the Byrd subglacial basin define a continuous topographic depression along the junction of the two subcontinents.

The seismic work of Houtz and Meijer (1970) and Houtz and Davey (1973) and some magnetic measurements reported by Adams and Christoffel (1962) constitute the bulk of the geophysical work previously reported for the Ross Sea. The former studies showed the existence of a major sedimentary basin underlying the eastern Ross Sea shelf which is separated from a more complex regional structure underlying the western Ross Sea shelf by a series of basement highs lying along the $180^{\circ}$ meridian. These basement highs appear to be continuous with the basement structures of Iselin Bank. Sonobuoy refraction measurements suggest that a north-south-trending trough of sediments up to $2.5 \mathrm{~km}$ thick underlies the central part of the western shelf. This trough was considered by Houtz and Davey to be relatively old as the seismic profiler records indicate that 


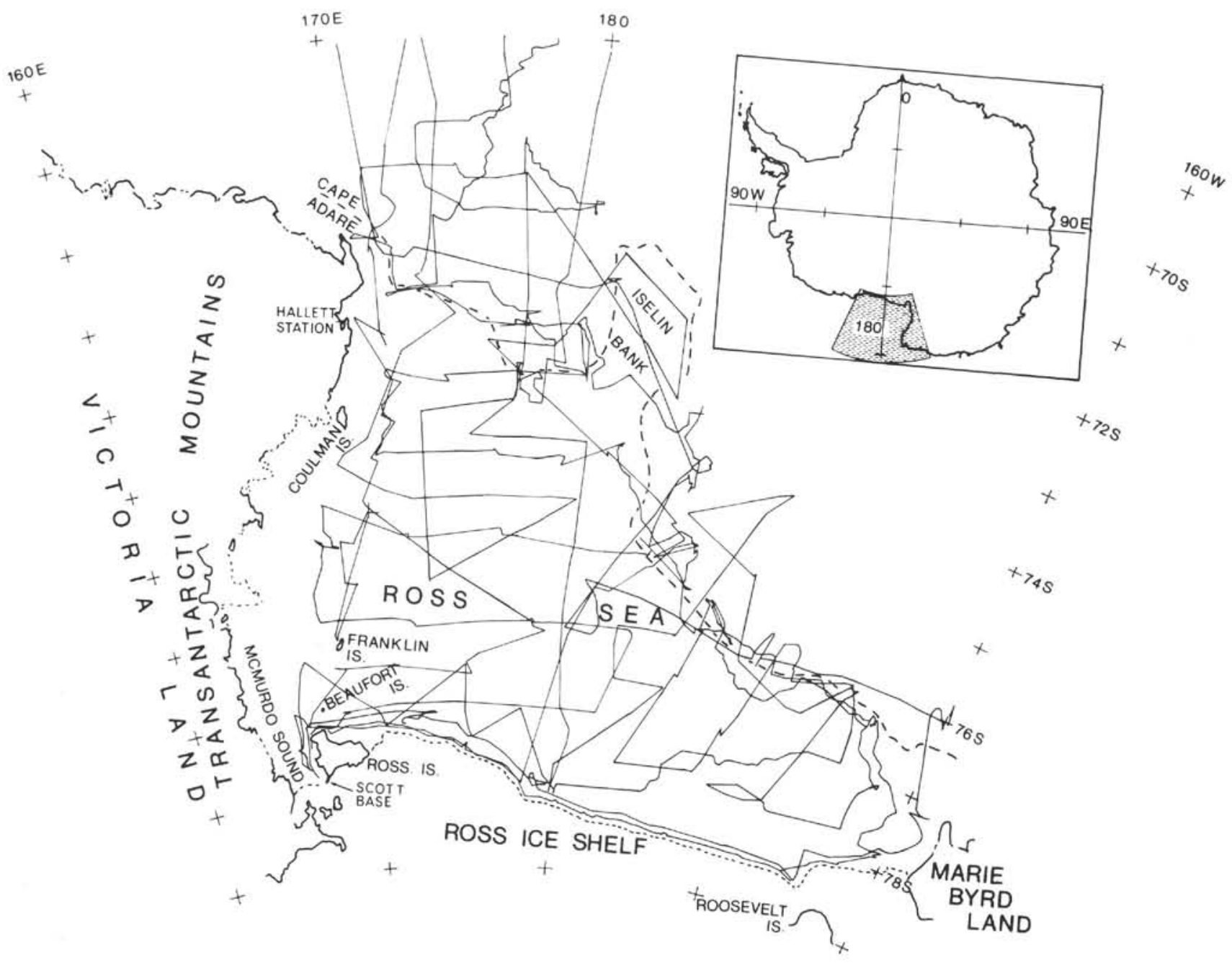

Figure 1. Location of the survey area, shown shaded on the inset outline of Antarctica, and track chart of Eltanin cruises.

the disposition of the sediments is unaffected by the deeper structures. Owing to the lack of large amplitude, small wavelength, total intensity magnetic anomalies, Adams and Christoffel (1962) postulated a "considerable thickness of presumably sedimentary rock" underlying the western Ross Sea. Gravity and magnetic measurements over the adjacent Ross Ice Shelf have been carried out by Bennett (1964) and by Ostenso and Thiel (1964).

Attempts at reconstruction of this portion of Gondwanaland by utilizing sea-floor-spreading magnetic lineations (Hayes and Ringis, 1973; Christoffel and Falconer, 1973) have illustrated the problems of unacceptable overlaps of various parts of the Australian and New Zealand continental blocks, especially the South Tasman Rise, with portions of the Ross Sea shelf and with Marie Byrd Land. Although unidentified variations in spreading conditions south of the PacificAntarctic ridge might account for some of these problems, alternatively, to resolve these problems some transcurrent movement between East and West Antarctica may be required and has been suggested by other authors, e.g., Hamilton (1967), Robinson (1964), Van der Linden (1967), Cullen (1968), and Hayes and Ringis (1973). The most favorable position for the dislocation line of this hypothetical transcurrent movement would be in the Ross Sea. The objectives of this study were to investigate evidence for such a dislocation and to examine parameters of the major Ross Sea structures previously defined by the seismic work of Houtz and Davey (1973).

\section{GEOPHYSICAL MEASUREMENTS}

\section{Bathymetry}

Bathymetric data were recorded along all the tracks shown in Figure 1, using a PDR recorder with a $12-\mathrm{kHz}$ transducer. For two cruises (slightly over half of the data), a $3.5-\mathrm{kHz}$ transducer was simultaneously used and gave subsurface information on the upper few tens of meters of sediments. The contoured bathymetric map of the Ross Sea is shown in Figures 2a and 2b (in back pocket). Depths in meters and corrected for variations in the velocity of sound in seawater after Matthews (1939) are generally contoured at 100 -meter intervals, with 40-meter contours shown over most of the Ross 


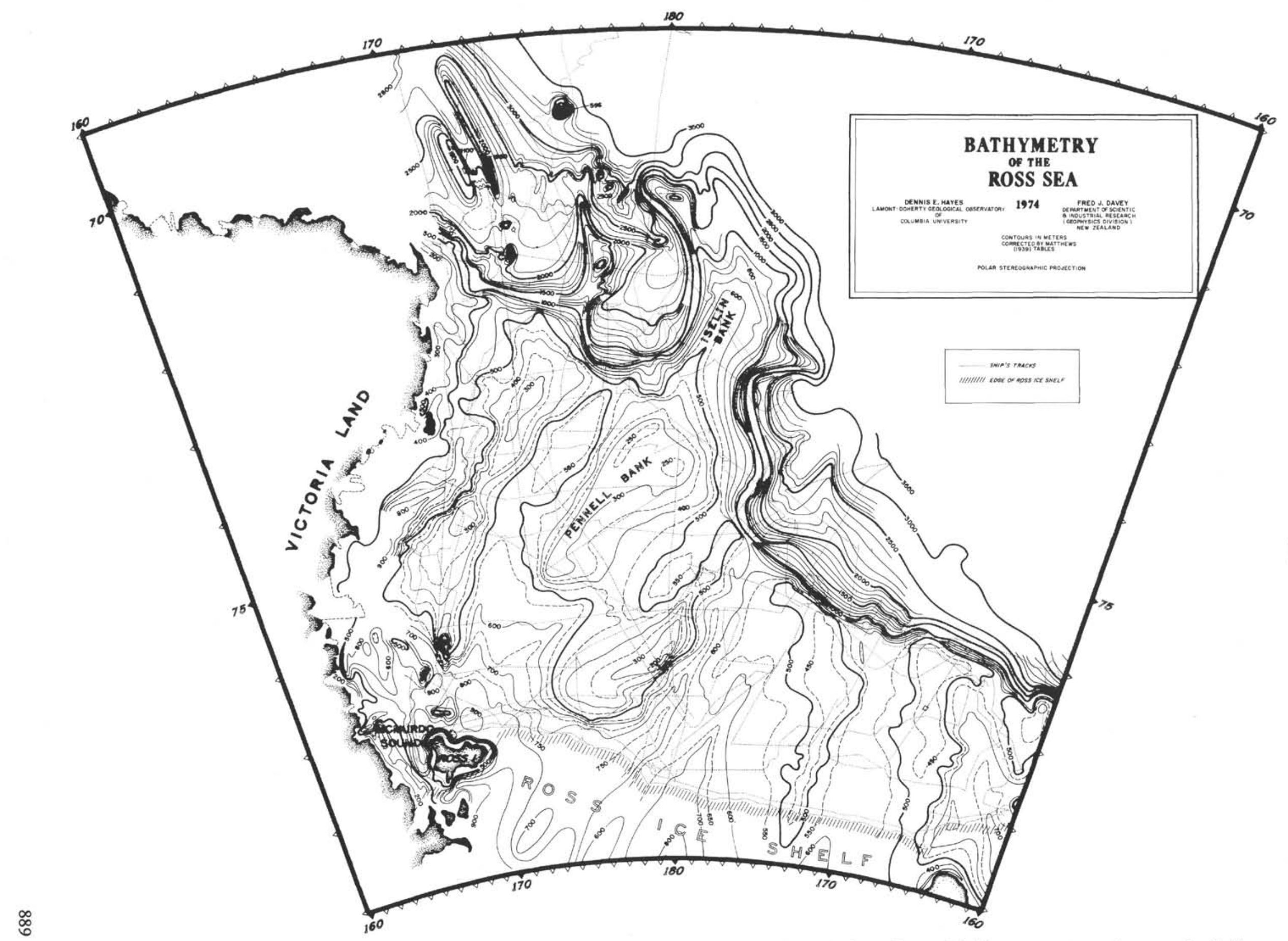

Figure 2. (a) Bathymetry of the Ross Sea. Contours at 100-meter intervals, 500-meter contours shown by heavy lines, with 50-meter contours shown on the shelf area by a long dashed line. (b) Colored foldout in back pocket. 
Sea shelf, and only 500-meter contours shown along the steep gradients of the continental slope. In the southwest, near the Victoria Land coast, bathymetric data provided by the United States Naval Oceanographic Office have also been used. No new data are presented for the submarine topography beneath the ice shelf. We note the same ridge and valley morphology is seen there as on the Ross Sea shelf, but that mean depths are apparently deeper beneath the ice shelf than either part of the Ross Sea shelf. Contours have been extrapolated beneath the Ross Ice Shelf to be consistent with the limited seismic reflection data of Crary et al. (1962) and Robinson (1963). In the northeast portion of the chart, and occasionally in areas between widely spaced Eltanin tracks, the contours are based on maps published by the American Geographical Society (1970) and Jacobs et al. (1970) and are shown dashed.

The area studied falls conveniently into four major physiographic regions, namely (a) western Ross Sea shelf, (b) eastern Ross Sea shelf, (c) Iselin Bank and the western continental rise, and (d) the eastern continental rise. The natural division of the Ross Sea shelf into eastern and western sections is immediately apparent from the bathymetric chart. Both areas are marked by elongate ridges which show a subtle change in orientation about the $178^{\circ}$ meridian, from north-south in the east to roughly northeast-southwest in the west. Furthermore, the mean depth in the western area is about 450 meters compared with 550 meters in the east, where the morphology is also more subdued. Houtz and Davey (1973) have also remarked that this dividing zone effectively separates two regions with differing seismic structures.

The mean depth of the Ross Sea shelf and the entire Antarctic continental shelf is two to three times greater than the average continental shelf depths elsewhere. This has often been taken as evidence for a regional depression of normal shelf depths by continental ice loading, although this explanation may be a gross simplification (see Hayes et al., this volume).

\section{Western Ross Sea Shelf}

The generalized topography over the western shelf consists of ridges and valleys with amplitudes of about 300 meters and wavelengths of $150-200 \mathrm{~km}$. The gradients seen on the western shelf reach about $1.6^{\circ}$ in places as compared with a maximum of $0.6^{\circ}$ in the eastern Ross shelf. The minimum depth recorded by USNS Eltanin on the shelf (not associated with islands) is 178 meters at $76^{\circ} 39^{\prime} \mathrm{S}, 179^{\circ} 32^{\prime} \mathrm{E}$. In the west of the region the sea-floor topography is modified in a few places by the Cenozoic volcanic activity. These volcanic cones rise above sea level to form (from north to south) Coulman Island, Franklin Island, Beaufort Island, and Ross Island. Apart from these four islands and possibly one or two shoal areas indicated on the American Geographical Society map immediately south of Franklin Island, there are no other bathymetric shoals that can be definitely associated with any volcanic activity.

Although data are incomplete, the greatest depths ( $>900 \mathrm{~m}$ ) seen on the Ross Sea shelf are found along the Victoria Land coast south of $74^{\circ} \mathrm{S}$. This linear deep may be related to the tectonic movements which occurred along the Victoria Land coast in association with uplift of the Transantarctic Mountains. North of $74^{\circ} \mathrm{S}$ sediments (that may have filled a previously existing deep close to the Victoria Land coast) are suggestive of prograded structures (Figure 3). Ross Island is nearly surrounded by a conspicuous moat reaching depths of 800 900 meters. This deep probably results in part from the downwarp of the crust by the load of the volcanic rocks of Ross Island. Southwest of Ross Island volcanic debris may have partially filled the moat.

The distribution pattern of microtopography types which have been identified on the shelf can be seen in Figure 4. Regions showing hyperbolic reflections and small-scale irregularities, Figure 5, tend to be confined to the valleys to the north and west and probably reflect the position of the strongest near-bottom currents on the shelf. Bottom current measurements by Jacobs et al. south-east

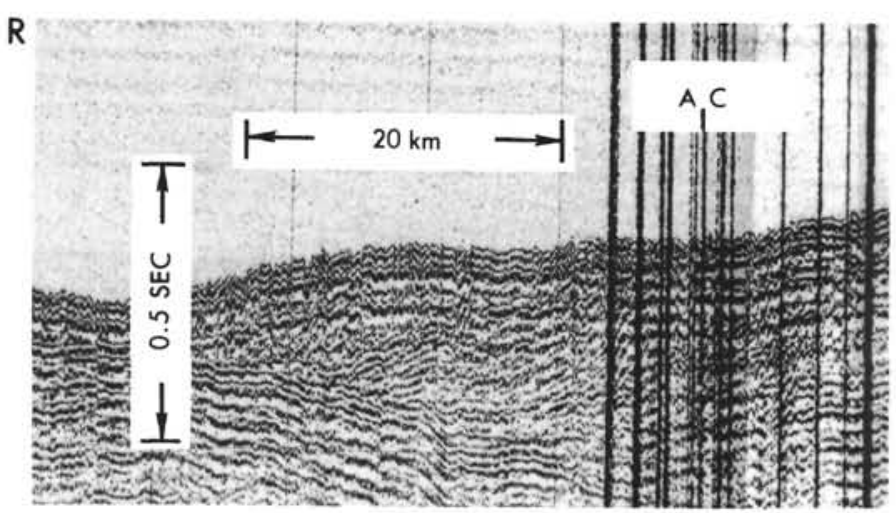

north-west

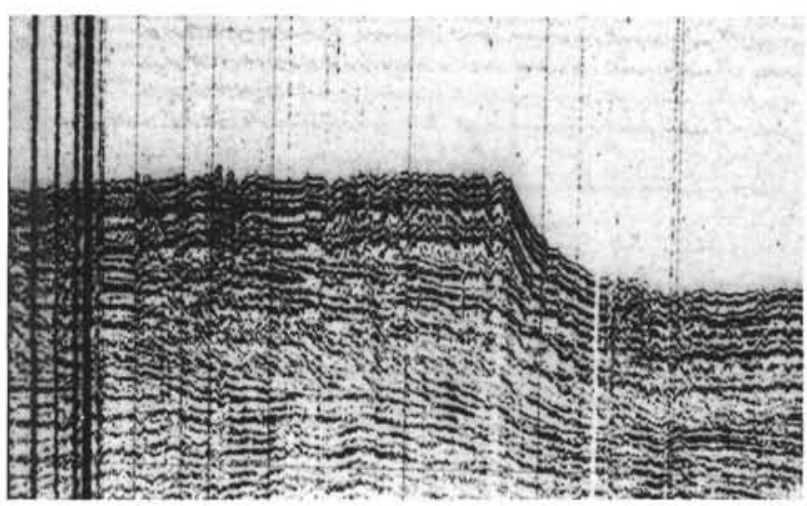

Figure 3. Photocopy of a profiler record (showing possible deltaic or prograded beds) along track $R$ of Figure 4 . The profile covers the western end of profile $C C^{\prime}$ and the southern end of profile $L L ' A / C$ marks a course alteration. $0.5 \cong 500$ sec meters of sediment. 


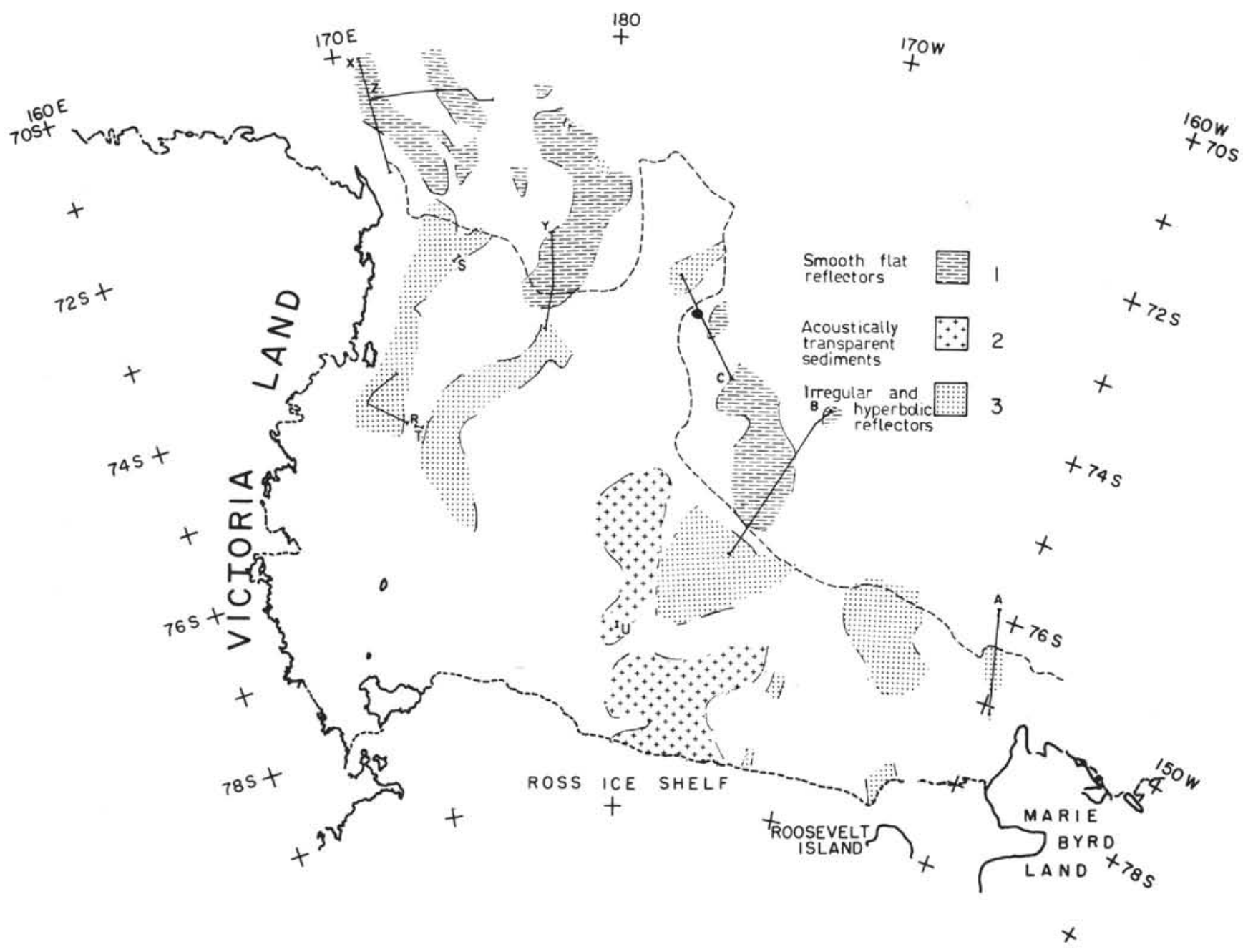

Figure 4. Microtopography regions for the Ross Sea as deduced from 3.5-kHz profiler records. The profiles in Figures 3 and 5-8 are located.

(1970) on the Ross Sea shelf gave velocities in the range 4-15 cm/sec, but no consistent direction was apparent.

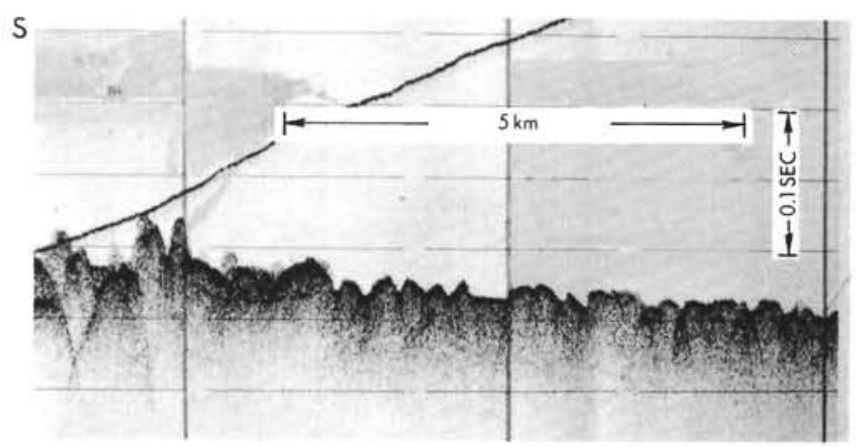

Figure 5. Photocopy of a 3.5-kHz profiler record showing the irregular and hyperbolic sea floor reflectors of region 3, Figure 4. 0.1-sec two-way reflection time corresponds to approximately 75 meters depth in water.
Near the shelf break the currents were usually stronger and in a northerly or westerly direction. The apparent wavelength of the features giving rise to hyperbolic reflection vary from about 100 to 400 meters with amplitudes of about 10 meters, and they could be caused by outcropping consolidated sediments or by current action building up sand waves or dunes. Sand dunes with wavelengths of up to 900 meters and with amplitudes of up to 12 meters have been reported on continental shelves by Cartwright and Stride (1958) and on a slightly smaller scale in the Thames estuary by Langhorne (1973). The 500-meter water depth of the Ross shelf and wide-angle configuration of the PDR instrumentation could give rise to the hyperbolic reflections seen instead of the true sea floor (sand dune) shape. Part of a $3.5-\mathrm{kHz}$ profiler record, Figure 6, shows the presence of hyperbolic reflectors randomly spaced at apparent depths of up to 40 meters below the sea floor. The source of these point reflectors is interpreted as large rocks $(>50 \mathrm{~cm})$ in a fine matrix, possibly a "boulder clay," one of the many possible products of known glacial action. 


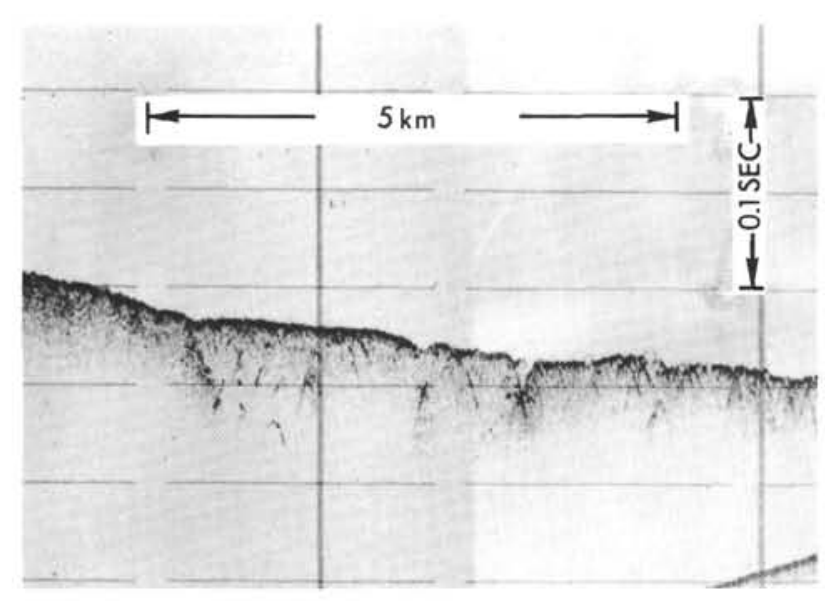

Figure 6. Photocopy of a $3.5-\mathrm{kHz}$ profiler record showing deep, point reflectors in an acoustically transparent sediment, Figure 4.

\section{Eastern Ross Sea Shelf}

The eastern Ross Sea shelf also has a subdued ridge and valley morphology but with an amplitude of about 150 meters and a remarkably consistent wavelength of about $150 \mathrm{~km}$. Houtz and Davey (1973) have shown that the north-south ridges are formed by banks of sediments overlying a series of truncated dipping beds. They considered that these ridges have retained more or less their present form since at least the late Miocene. The localized deeps of up to 800 meters found close to Marie Byrd Land are probably caused by local land glaciers, or ice flowing between Marie Byrd Land and Roosevelt Island, at some time in the past. Roosevelt Island, about $50 \mathrm{~km}$ south of the ice shelf edge, marks a topographic high suggested by Bennett (1964) to be caused by a granitic intrusion. The small-scale topography is smooth but with some areas marked by short wavelength irregularities and hyperbolic reflections on the PDR records, Figure 6 . In the region of $78^{\circ} \mathrm{S}, 178^{\circ} \mathrm{W}$, thin, patchy banks of acoustically transparent material are seen on the 3.5-kHz PDR recordings, Figure 7, Figure 4. These sediments are interpreted as banks of mud of marine glacial origin, up to 20 meters thick. Near the seaward edge of the shelf the sea floor rises by a few tens of meters to form a low, discontinuous ridge subparallel to the shelf edge.

\section{Western Continental Rise}

The western continental rise and slope are complex in character. The shelf break lies at 500-600 meters and changes in orientation from approximately north-south to east-west in a series of abrupt steps. The continental slope has a gradient of about $4^{\circ}$, Figure 8 , profiles $X$ and Y. The top of Iselin Bank (see Figure 2) deepens gradually northwards from about 500 meters where it abuts the main Ross shelf to about 1000 meters at $71^{\circ} 30^{\prime} \mathrm{S}$. The northerly extension of Iselin Bank, separated by a deep sedimentary basin from the eastern part of the bank, curves around to a north-northwest orientation. At about $177^{\circ} \mathrm{E}$ there is a series of bathymetric highs aligned just east of north including a sea-

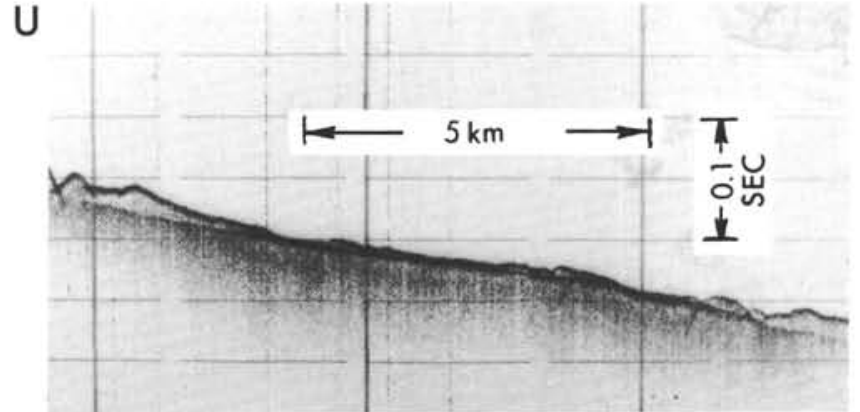

Figure 7. Photocopy of a $3.5-\mathrm{kHz}$ profiler record showing the transparent sediment banks of region 2, Figure 4.
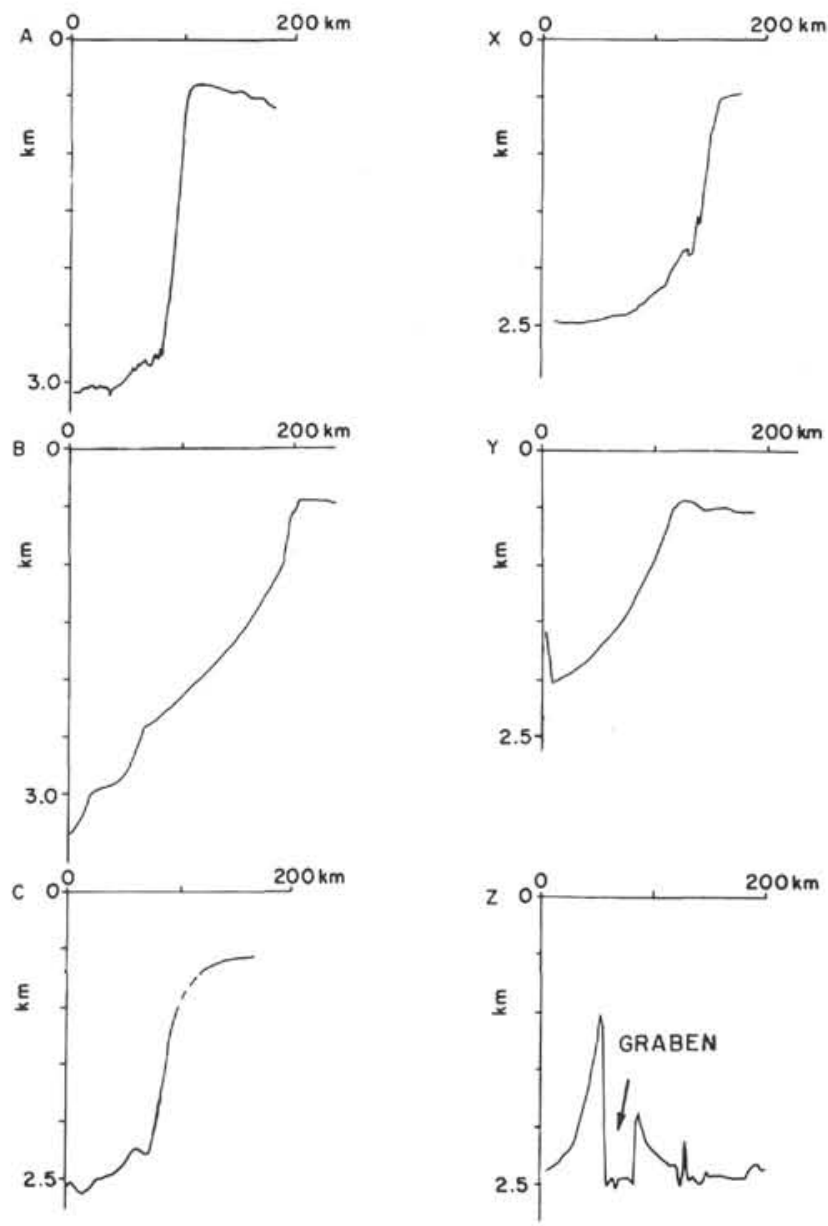

Figure 8. Bathymetric profiles across the continental slope and rise. The profiles are located in Figure 4. Vertical exaggeration approximately 100:1.

mount at the northern end of this line that reaches to within 600 meters of the sea surface. Near $174^{\circ} \mathrm{E}$ a low, but distinct, ridge strikes northwards from the continental slope to about $71^{\circ} 21^{\prime} \mathrm{S}$, where a deep sediment-filled trough occurs (P on profile LL', Figure 19). This trough contains about 500 meters of sediments and lies along the trend of a distinctive graben feature to the northwest, Figure 8, profile $Z$ (see also Houtz and Davey, 
1973, fig. 15). The trough may result from the same tectonic forces which formed the graben.

The graben trends north-northwest and is asymmetrical, being considerably lower on the eastern side than the western side. The slopes of the flanks of the graben reach $2.5^{\circ}$. The total measurable vertical displacement across the basement along the fault forming the western side of the graben is of the order of 2000 2500 meters and is about 1000-1500 meters for the eastern fault. The overall longitudinal extent of the graben as a major feature is about $150 \mathrm{~km}$. It dies out near $170^{\circ} \mathrm{E}$ where our data coverage stops, but data from other sources (e.g., Hayes and Wall, Chapter , this volume) indicate that similar features may occur further to the north and west, along the line of the major graben.

The ridges on the continental rise have formed sediment traps, especially Iselin Bank, where up to $3 \mathrm{~km}$ of sediments occur in two main sedimentary troughs (Houtz and Davey, 1973). The 3.5-kHz PDR data over these sediments show strong reflectors parallel to and up to 40 meters beneath the sea floor, Figure 5 . Immediately north of the east-west basement ridge separating these troughs, a submarine channel starts and runs through the northern basin and can be traced as far north as $60^{\circ} 30^{\prime} \mathrm{S}$, Figure 9a, b. The 3.5-kHz PDR records show hyperbolic reflections on the walls of the channel south of $70^{\circ} \mathrm{S}$ indicating that the sedimentary layers outcrop there and thus either erosion is active within the channel or deposition is being prevented by a reasonable flow of water through the system. Another channel, of smaller dimensions, is seen farther west near the eastern side of the graben, Figure 9a.

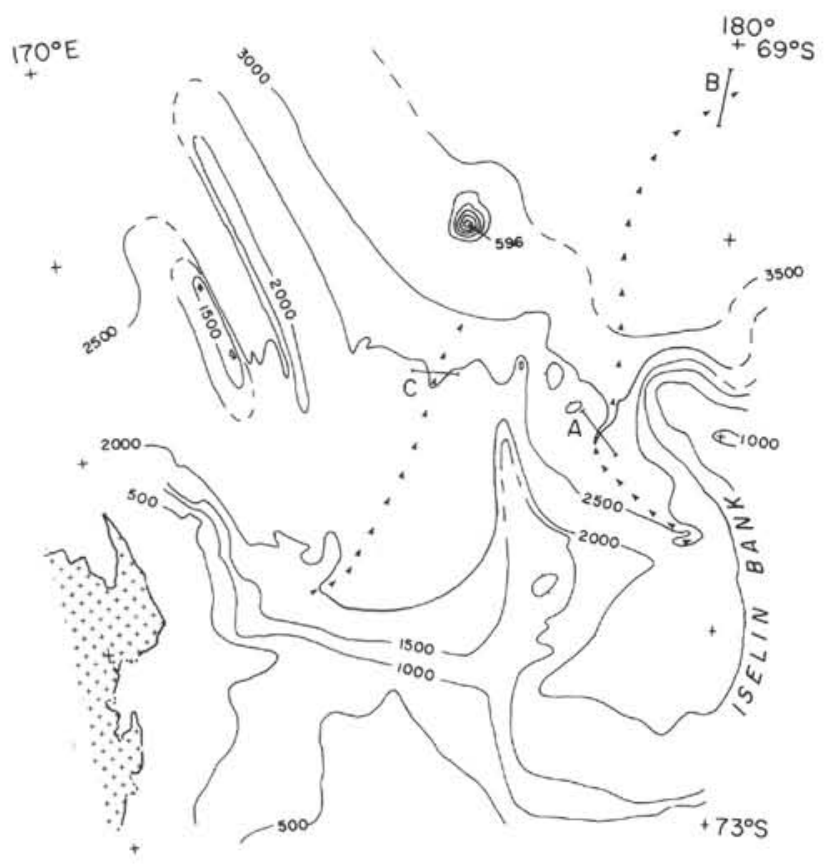

Figure 9a. Bathymetric contour map of the western Ross Sea rise. Depths are in meters. The positions of two submarine channels are shown by the line of arrowheads.

\section{Eastern Continental Rise}

The morphology of the continental rise east of Iselin Bank appears relatively simple although data in this province are relatively sparse. The gradients of the continental slope and upper rise decrease from east and west towards the $175^{\circ} \mathrm{E}$ meridian, from a maximum of $7.5^{\circ}$ at $160^{\circ} \mathrm{W}$ to about $1.0^{\circ}$ at $172^{\circ} \mathrm{E}$, Figure 8 , profiles $\mathrm{A}$ and B. The portion of the continental slope with a gentle gradient coincides with the seaward extension of the
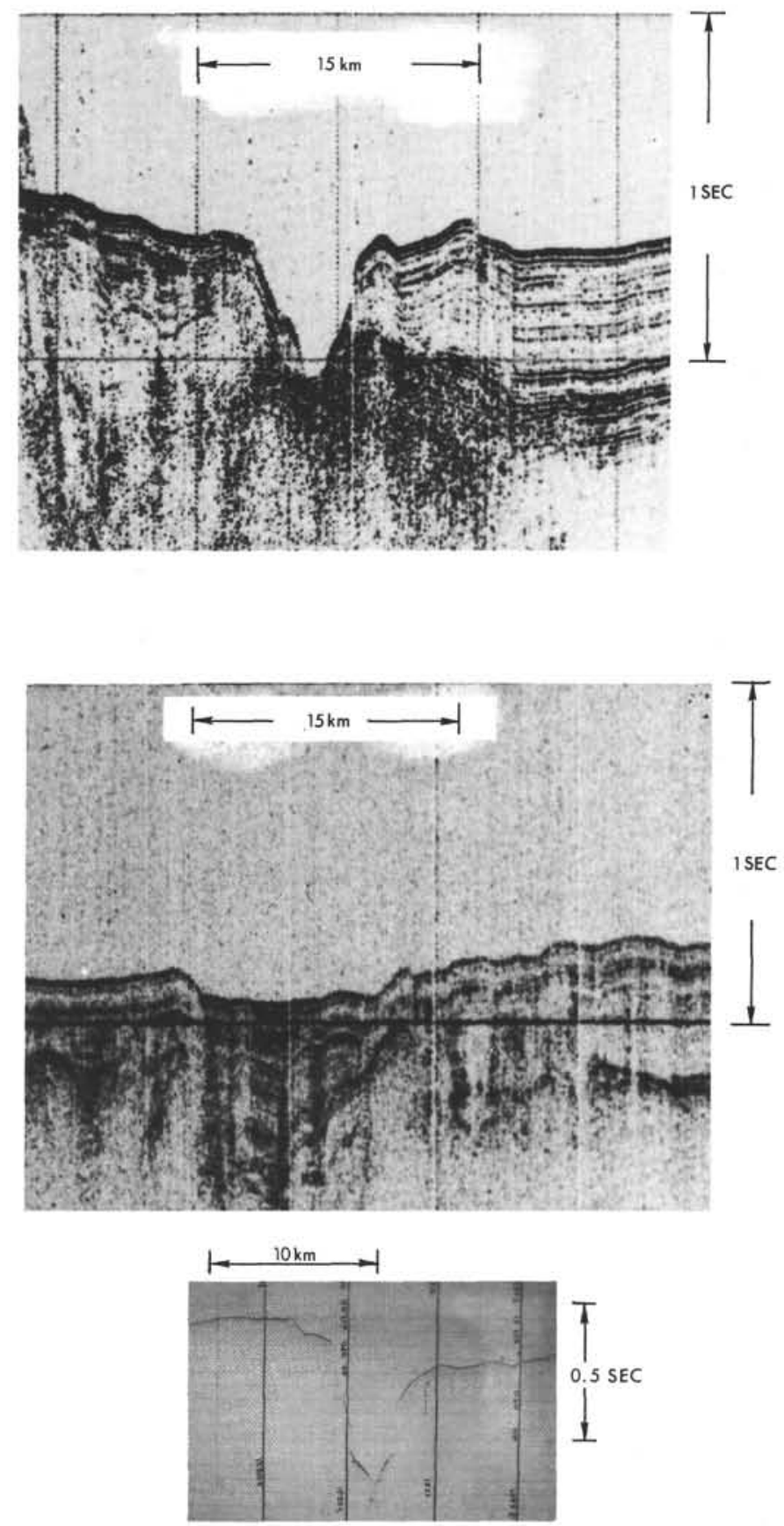

Figure 9b. Profiler (airgun for profiles $A$ and $B$ and $12-k H z$ PDR for profile C) records across sections of the channels are shown on the right. 
sedimentary basin which underlies the eastern Ross shelf (Houtz and Davey, 1973). The 3.5-kHz PDR data across this section of the continental slope show that the upper part is covered by smooth sediments showing subbottom reflectors up to 50 meters deep (Figure 4). A southsouthwest-dipping layer which outcrops on the sea floor at a depth of 2500 meters, and mentioned by Houtz and Davey, shows an irregular surface with a relief of up to 40 meters but no subbottom reflections. Elsewhere, to the east and west, the slope topography is rough with some sediment ponding occurring near the base of the slope.

\section{Gravity}

The gravity data were recorded using a Graf-Askania Gss2 sea gravimeter mounted on an Anschütz gyroplatform. The gravimeter cross-coupling error was recorded continuously. The data were corrected for cross-

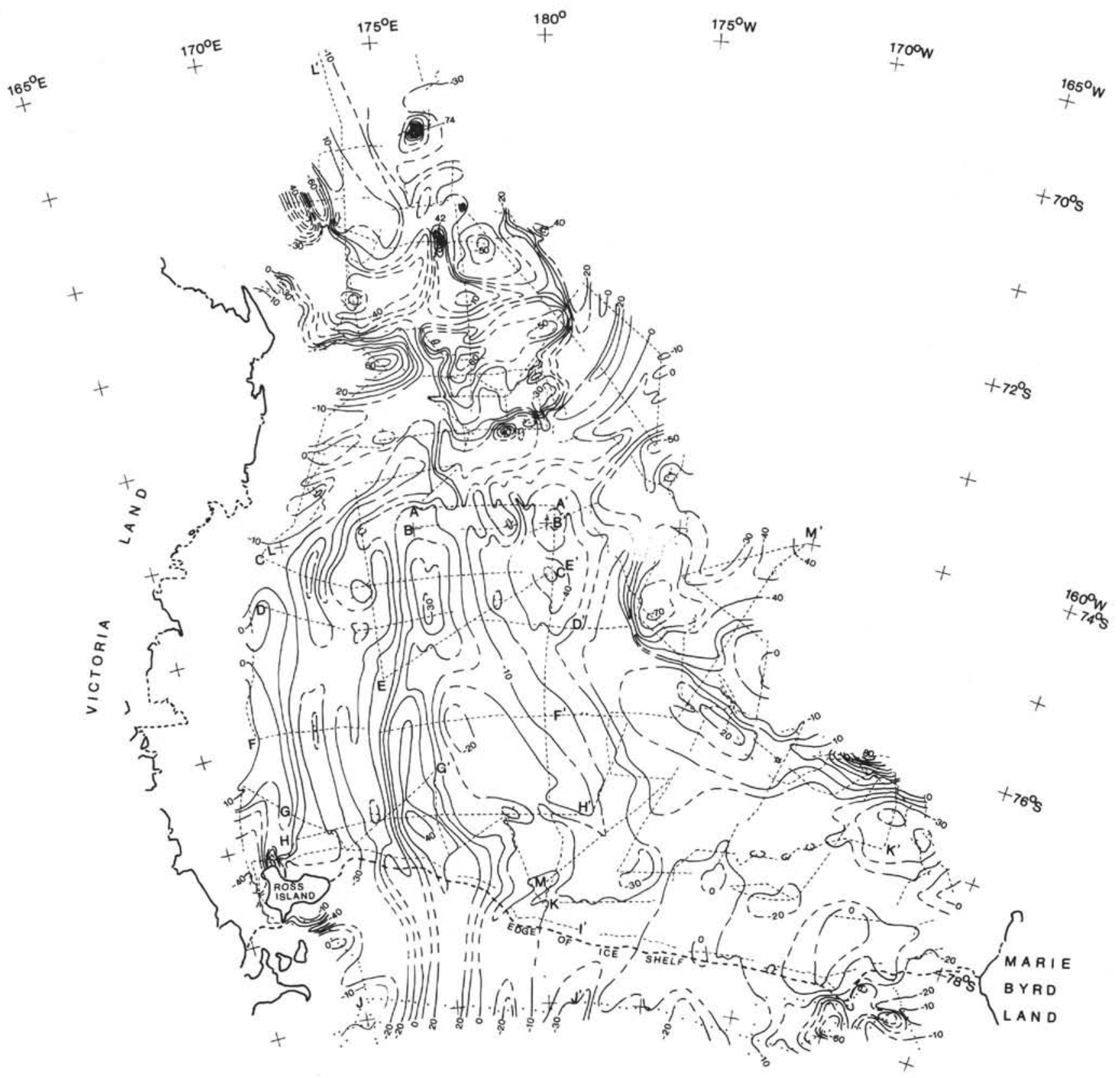

Figure 10a. Free-air gravity anomaly map of the Ross Sea. Contours are at 10-mgal intervals. The ship's track where data were obtained is shown by the dashed line and ice-shelf stations by dots. Profiles AA' through MM', shown in Figures 15 through 19, are located. 
coupling and reduced to free-air anomalies and errors. Mean discrepancy at track intersections is $2.4 \mathrm{mgal}$ for 48 intersections with a maximum discrepancy of 8.4 mgal. The data have been contoured at 10 -mgal intervals and are shown in Figure 10a along with the ship's track where data were obtained. Data on the Ross Ice Shelf (Bennett, 1964) have also been included.

The major free-air anomalies on the Ross Sea shelf are the linear positive anomaly, lying approximately along $175^{\circ} \mathrm{E}$ from $74^{\circ} \mathrm{S}$ to the edge of the ice shelf, and the flanking negative anomalies to the east and west. The linear gravity belts cut across the major topographic trends, Figure $10 \mathrm{~b}$. The ice shelf data indicate that the main positive anomaly extends south, to about $80^{\circ} \mathrm{S}$ or perhaps further southeast, -parallel to the trend of the
Transantarctic Mountains. This gravity anomaly belt extends over a distance of $700 \mathrm{~km}$ and has a peak-topeak amplitude of about $80 \mathrm{mgal}$, with a maximum positive anomaly of $45 \mathrm{mgal}$. Superimposed on the broad flanking low to the west are some short wavelength negative anomalies which for the most part are apparently continuous in a north-south direction, but swing to the northeast at their northern end. The flanking gravity low to the east of the positive anomaly is a broad feature which reaches the minimum value for the shelf, $-53 \mathrm{mgal}$, at $74^{\circ} 40^{\prime} \mathrm{S}$.

An isolated gravity low occurs at the eastern edge of the Ross Sea shelf (near $75^{\circ} \mathrm{S}, 175^{\circ} \mathrm{W}$ ). Several isolated positive anomalies occur near the shelf edge, especially where the continental slope is steep at either end of the

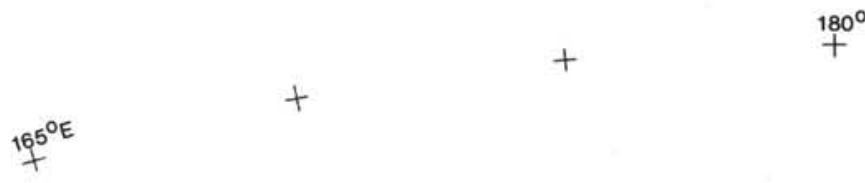

$+$

$165^{\circ}$

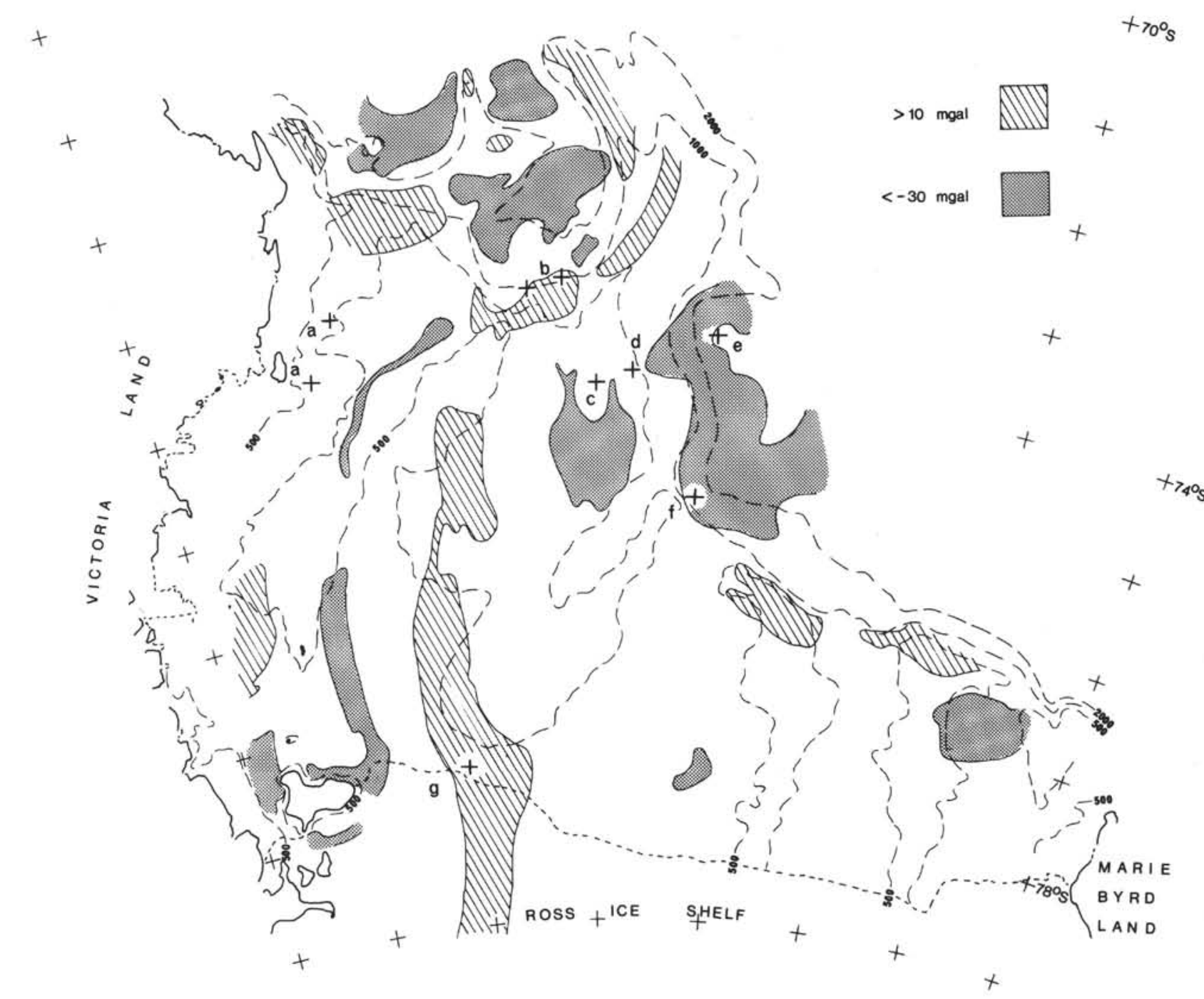

Figure 10b. The position of the major gravity anomalies in relation to the regional morphology of the Ross Sea shelf. Anomaly values greater than +mgal and less than -30 mgal are shown shaded. The 500-,1000, and 2000-meter depth contours are shown and the position of the major magneric anomalies, " $a$ " through " $g$ ", Figure 13, are marked by crosses. 
Ross Sea and these may be partially accounted for by the isostatic "edge effect." A low linear positive anomaly runs along the top of Iselin Bank. The large anomaly at the southwest end of Iselin Bank coincides with a basement rise seen on seismic profiler records.

Figure 11 shows the free-air anomaly averaged over "squares" of one degree of latitude by four degrees of longitude and contoured at 10 -mgal intervals. This shows clearly the lack of any significant anomaly over the eastern sedimentary basin and the absence of any large regional variations (of this scale) in the gravity field. The mean anomaly over the Ross shelf is -12.9 $\mathrm{mgal}$ and is close to that derived for the Ross Ice Shelf, $12.0 \mathrm{mgal}$ (Bennett, 1964). The prominent linear gravity high retains its "identity" through this averaging process.

\section{Magnetic}

The magnetic data were recorded using a Varian proton precession magnetometer. Few large anomalies with amplitudes of $500 \mathrm{nT}$ ( 500 gammas) or greater occur over the Ross Sea shelf. The problem of producing a contour map of the total magnetic field is complicated by the presence of large diurnal and magnetic storm variations and a limited knowledge of the secular variation in the area. The magnetic anomalies were computed by first removing the IGRF (IAGA, 1969) from the observed data. Analysis of the resulting anomalies indicated that the average values for these anomalies were widely different for the data collection period from 1967 to 1972 . A mean anomaly was therefore computed for each cruise, for that portion south of $70^{\circ} \mathrm{S}$, and subtracted from the observed anomaly.

Over most of the shelf the amplitudes of the anomalies are small and an obvious 24-hour periodicity was noted on available time series data recorded over

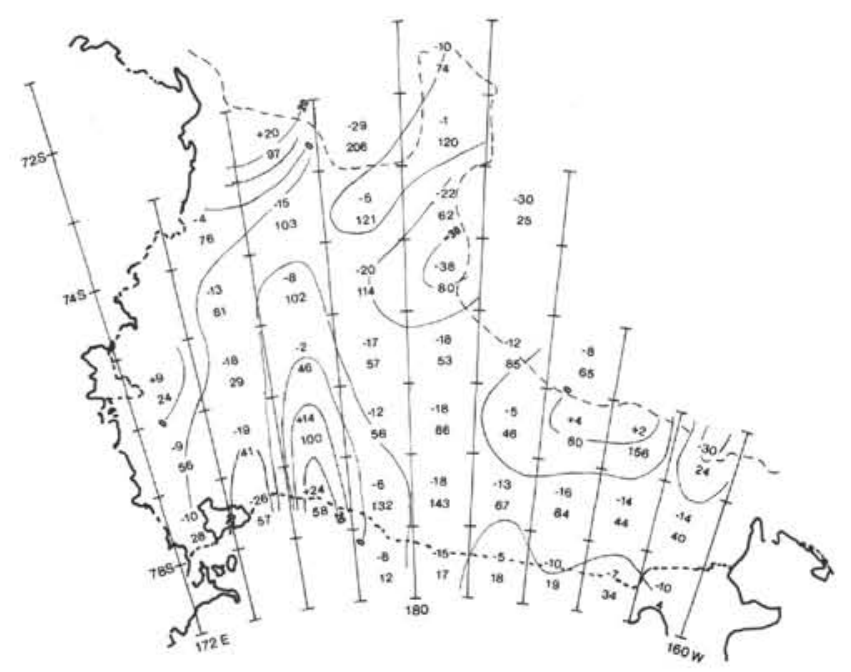

Figure 11. Mean free-air anomalies for the Ross Sea shelf. The upper figure gives the mean anomaly and the lower figure the number of observations in the "square" $1^{\circ}$ lat. $\times 4^{\circ}$ long.) The data are contoured at 10-mgal intervals. magnetically quiet areas, Figure 12 . An attempt was made to remove a diurnal component from the observed data, although this was difficult for a number of reasons. First, the only observatory in the vicinity recording magnetic field variation during the period of interest was Scott Base on Ross Island, Figure 1, which is situated in the southwest corner of the survey area. Secondly, the proximity of the survey area to the southern magnetic pole and the aurora zone can give rise to significant spatial variation in the diurnal effect. Thirdly, the presence of a continental shelf edge in the survey area which can lead to a phase change and amplification of the diurnal component (Roden, 1963). During 1957-1958 magnetic data were recorded at Hallett Station, at the northern end of the survey area, Figure 1, as well as Scott Base, and the daily magnetic variations recorded for both stations showed a similarity in amplitude (about $200 \mathrm{nT}$ ) and phase. Furthermore, the observed anomaly over magnetically quiet parts of the survey area shows quite a close correspondence to the observed daily variation at Scott Base, Figure 12, although anomaly amplitudes at Scott Base are apparently smaller. These results indicated that if the Scott Base daily variation corrections were to be applied over the whole survey area, this should improve any discrepancies in the observed magnetic field at track intersections. The discrepancies between observed magnetic field values at track intersections gave an rms error of $112 \mathrm{nT}$ for 59 intersections, after application of the Scott Base daily variation an rms error of $93 \mathrm{nT}$ was obtained. No adjustment was made for local geomagnetic time as the region represents less than a 2 -hr variation (Penndorf, 1965) and other uncertainties preclude the value of such detailed corrections. Any magnetic storm variations, that also influence the 1-hr observed values, should occur simultaneously over the region (Nagata, 1962). The improved fit at track intersections is not great, and it was considered better to apply the correction only to the shelf area where the anomalies are generally small, especially as the diurnal variations over the shelf edge and adjacent deep oceans are uncertain (Rikitake, 1966; Roden, 1963). Most of the larger discrepancies (greater than $150 \mathrm{nT}$ occur where either the regional magnetic gradient is large, and thus may result in part from navigational uncertainties, or when the Scott Base daily variation was very large. In view of the inferred accuracy of the data, the map of the total magnetic force anomaly has been contoured at $200 \mathrm{nT}$ intervals (Figure 13).

The resulting map defines only a few major anomalies, Figure 13, and is consistent with the limited data of Adams and Christoffel (1962). A group of anomalies, "a" in Figure 13, lies close to Coulman Island and is probably related to the Cenozoic volcanics of the McMurdo Volcanic Group which occur both at Coulman Island and at Cape Adare further north. The postulated volcanic rocks causing the anomalies must occur at considerable depth as no correlatable structure can be seen on the seismic profiler records crossing the anomalies. There is a small gravity anomaly associated with these magnetic anomalies, see profile LL'. Further 


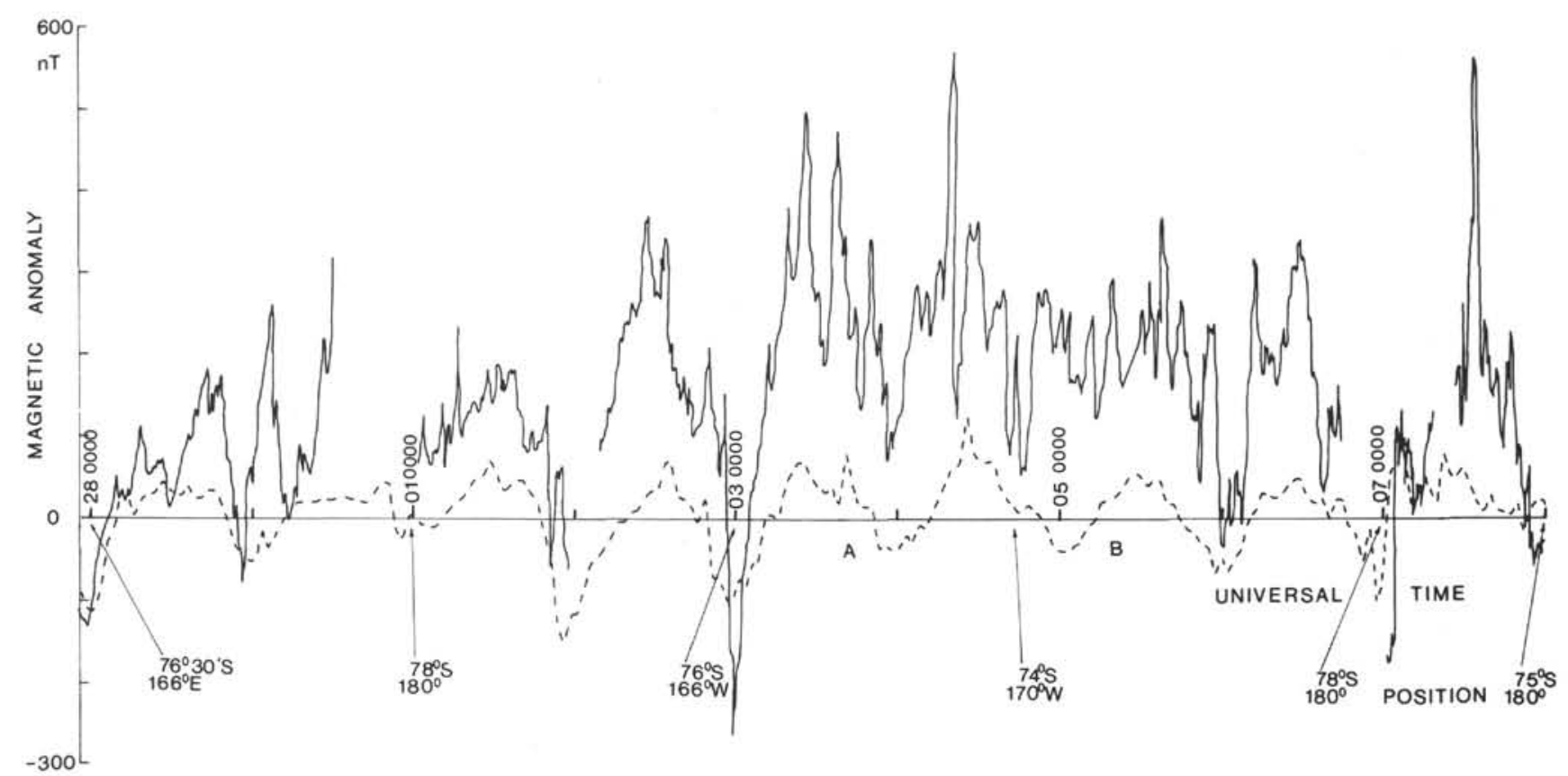

Figure 12. Plot of the observed magnetic anomaly (solid line) against time, showing a 24-hour periodicity in the observed data. Time is marked in days and hours. The Scott Base daily variation is shown beneath as a dashed line. The position of the ship's track is shown at intervals. The section between $A$ and $B$ was recorded off the shelf.

east is a major anomaly, "b" in Figure 13, which has an amplitude of about $1100 \mathrm{nT}$ and is also associated with a large positive gravity anomaly. Two positive anomalies of similar amplitudes but covering smaller areas occur to the southeast of "b" at "c" and "d" (Figure 13). These anomalies are all associated with shallow acoustic basement and with positive gravity anomalies. Anomalies "b," "c," and "d" lie near the junction of Iselin Bank with the main Ross Sea shelf as does the smaller anomaly "e" with an amplitude of $500 \mathrm{nT}$. Further to the southeast is a double linear positive anomaly, "f" in Figure 13, which strikes across the continental slope. This anomaly has an amplitude of about $500 \mathrm{nT}$ and the southern branch coincides with the basement ridge noted by Houtz and Davey (1973) (Figure 14). They considered the ridge to mark the western boundary of the sedimentary trough underlying the eastern Ross Sea shelf. The absence of significant anomalies over the eastern Ross Sea shelf proper is consistent with the presence of a thick sedimentary sequence in this area. At the southern end of the western Ross Sea shelf an elongate anomaly ("g," Figure 13) has an amplitude of $600 \mathrm{nT}$ and trends in a northeast direction. It is aligned with an anomaly found over the northern part of the Ross Ice shelf by Ostenso and Thiel (1964) but apparently decreases in amplitude further to the south as Bennett (1964) found no significant magnetic anomalies in the area. Northwest of the Ross Sea shelf the major anomalies are associated with a complex system of ridges and seamounts.

\section{INTERPRETATION AND DISCUSSION}

\section{Western Ross Sea Shelf}

The linear positive gravity anomaly trending northsouth across the western Ross Sea is a major feature of the shelf. Generally, the positive gravity anomaly is not associated with any large magnetic anomaly, and Houtz and Davey (1973) have shown that thick sediments are present in the same area. A series of east-west gravity and magnetic profiles aligned with respect to the gravity maximum are shown in Figures 15 and 16. The major gravity anomalies show a slight east-west asymmetry. Although the magnetic data in general show little correlation with the gravity anomaly, profile CC' shows a slight positive magnetic anomaly which may be related to the gravity anomaly. Profile II' shows a large positive magnetic anomaly coincident with the gravity anomaly, but a consideration of the gravity and magnetic contour maps indicates that the two signatures are probably not related to a common body. Two profiles, $\mathrm{CC}^{\prime}$ and $\mathrm{HH}^{\prime}$ were selected for more detailed consideration as they have better seismic control along them. They are shown in Figure 17 together with bathymetric and seismic data (after Houtz and Davey, 1973). A local Airy isostatic anomaly was computed for each profile based on a mean crustal density of $2.7 \mathrm{Mg} / \mathrm{m}^{3}(2.7 \mathrm{~g} / \mathrm{cc})$, a mantle density of $3.3 \mathrm{Mg} / \mathrm{m}^{3}(3.3 \mathrm{~g} / \mathrm{cc})$, and the bathymetry along the profile.

The deep seismic data (although limited) have been used to construct a model for the basement topography. The seismic data show a linear increase in velocity (Vp) with depth (Houtz and Davey, 1973) which has been related to densities using the results of Nafe and Drake (in Talwani et al.,1959). For ease of calculation, a number of layers with uniform densities was assumed for the sediments. Over the trough the deep seismic layer reached maximum velocities of only 4.0 to $4.5 \mathrm{~km} / \mathrm{sec}$ whereas basement velocities of about 5 $\mathrm{km} / \mathrm{sec}$ were expected (Houtz and Davey, 1973). The depth to basement in these areas was arbitrarily assumed to be about $0.5 \mathrm{~km}$ deeper than the depth to the 


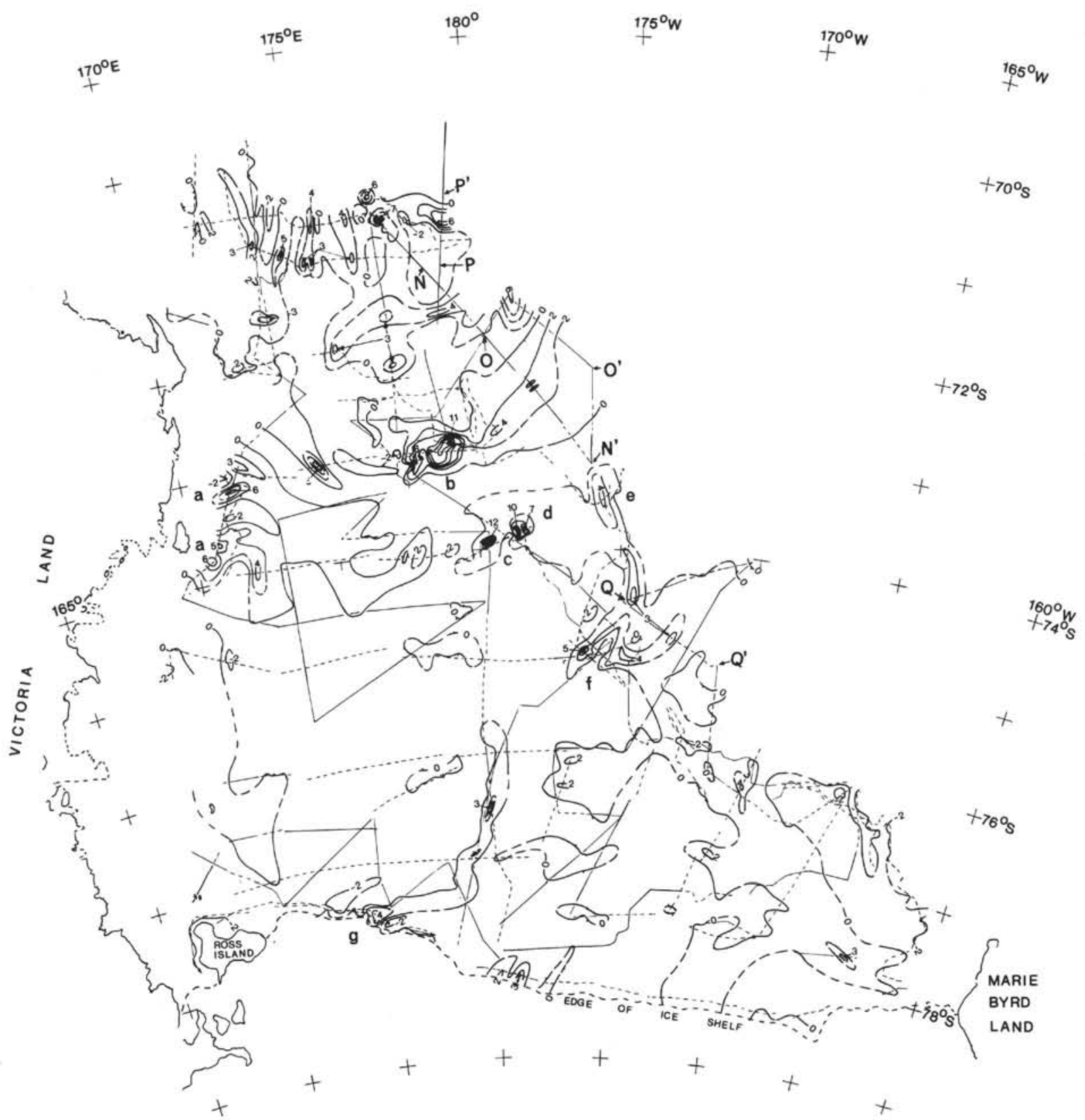

Figure 13. Magnetic anomaly map of Ross Sea. Contours are at 200-nT intervals. The ship's track is shown by a solid line where the " $K$ " indices were less than 3 and by a dashed line where the indices are greater or equal to 3. For Scott Base $\mathrm{K}=9$ corresponding to $2000 \mathrm{nT}$. Anomalies referred to in the text as " $a$ " through " $\mathrm{g}$ " and profiles $N N^{\prime}$ through $Q Q$ ' (Figures 14 and 20) are located.

4.0 to $4.5 \mathrm{~km} / \mathrm{sec}$ sediments. At this depth the sediment velocity would have a reached a value of about 5.0 $\mathrm{km} / \mathrm{sec}$ if the velocity-depth relationship deduced by Houtz and Davey (1973) is valid. The models assumed are shown by the dashed lines in Figure 17. The eastern boundaries of the trough can be fairly well located by seismic data, but in the west more variation is possible and the western boundaries used in the models are based in part on the observed gravity data.

A density of $2.7 \mathrm{Mg} / \mathrm{m}^{3}$ was assumed for basement rocks. The gravity effect of replacing the sediments in the above models by rocks of this density was computed and applied to the isostatic anomaly to give the "corrected" gravity anomaly shown in Figure 17. The high-density rocks giving rise to the residual positive gravity anomaly could be caused either by intrabasement petrologic contrasts or the relief of a basement ridge with uniform density. As the thickest sediments were measured over the maximum gravity anomaly, the high-density rocks were assumed to be intrabasement in nature. A simple regional gravity gradient, shown dashed in Figure 17, was removed before model fitting. Two basic models were used to fit the "corrected" gravity anomaly, model 1 assumes a high-density layer immediately below the sediments, and model 2 assumes a high-density layer at the base of the crust (the possible 


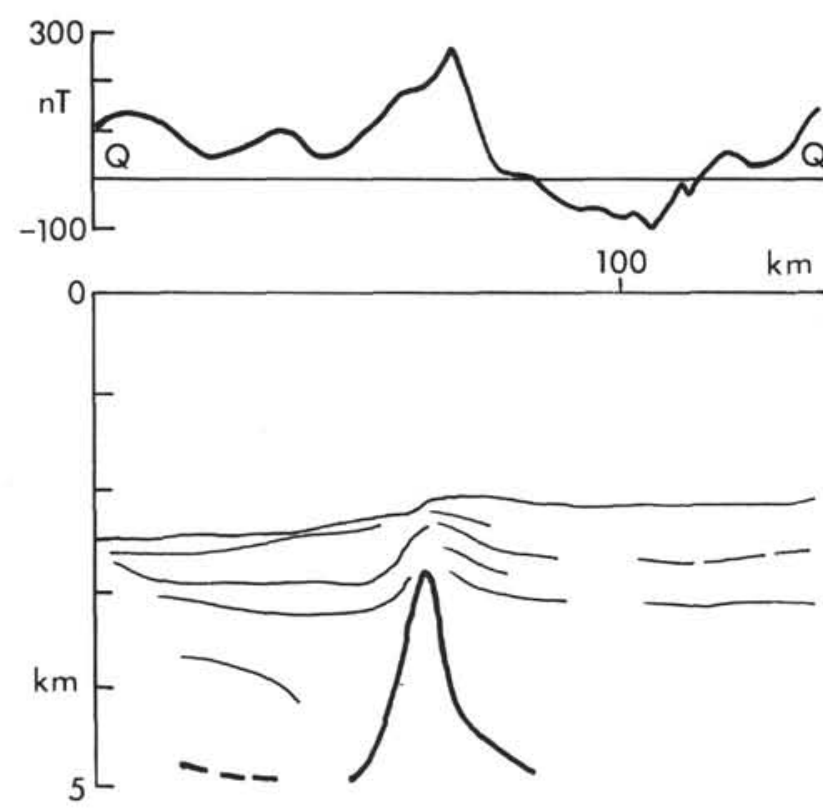

Figure 14. Bathymetric, seismic, and magnetic data along profile $Q Q$ ' across the basement ridge on the eastern continental rise (location, Figure 13).

manifestation of a thinning crust). One set of models is shown for each profile in Figure 17. The assumed crustal thickness $(30 \mathrm{~km})$ is consistent with that derived by Evison et al. (1960), Kovach and Press (1961), Bentley and Ostenso (1962), and Woollard (1963). Models intermediate in type between models 1 and 2 could invoke an increase in density for the whole section of crust underlying the positive anomaly.

Figure 17 also shows the "best-fit" magnetization computed for the shallow bodies (model 1) assuming that they are homogeneously magnetized. $\mathrm{M}$ is the direction of the present magnetic field in the plane of the profile, GM is the direction of the computed "best-fit" magnetization, the latter coincides with $\mathbf{M}$ for profile $\mathrm{CC}^{\prime}$. The magnetizations derived for profiles $\mathrm{CC}^{\prime}$ and $\mathrm{HH}^{\prime}$ were $0.9 \mathrm{~A} \mathrm{~m}^{-1}\left(0.9 \times 10^{-3} \mathrm{emu} / \mathrm{cm}^{3}\right.$ and $0.4 \mathrm{~A} \mathrm{~m}^{-1}$ $\left(0.4 \times 10^{-3} \mathrm{emu} / \mathrm{cm}^{3}\right)$, respectively.

The results show that unless very steep dips are assumed for the crust-mantle interface $\left(70^{\circ}\right)$, a model involving crustal thinning (model 2 ), will not fit the observed gravity data. Therefore, a model assuming a high-density layer (model 1), or increase in mean crustal density over a strip of crust $50 \mathrm{~km}$ wide and several hundred kilometers long is derived as the preferred interpretation. The "corrected" gravity anomaly shows a regional increase in gravity to the west which may be interpreted as a gradual thinning of the crust in this direction of about $0.5 \mathrm{~km} / 100 \mathrm{~km}$, but one should note that the sparse seismic control for the sediment model in the western region allows significant variations in the computed "corrected" gravity there.

In profile $\mathrm{CC}^{\prime}$ the negative eastern gravity anomaly is, in part, due to a local minimum of about $-50 \mathrm{mgal}$ which

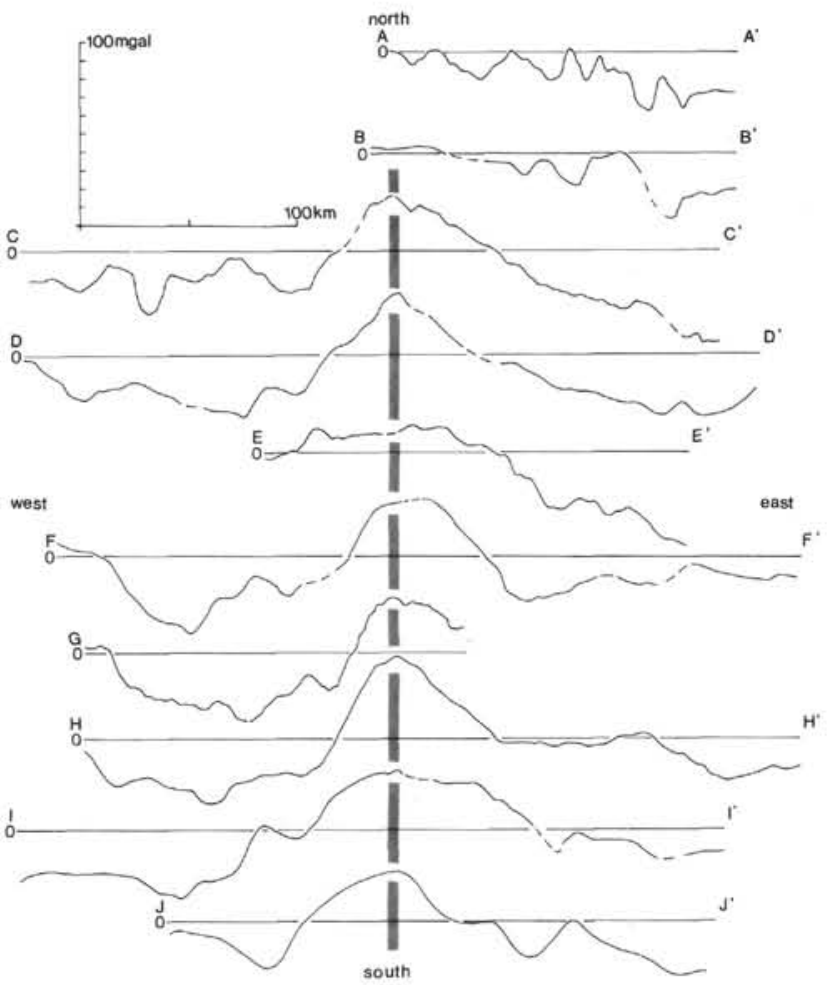

Figure 15. Free-air gravity anomaly profiles across the western Ross Sea shelf and aligned along the maximum of the western gravity high, marked by the vertical stripe (location, Figure 10a).

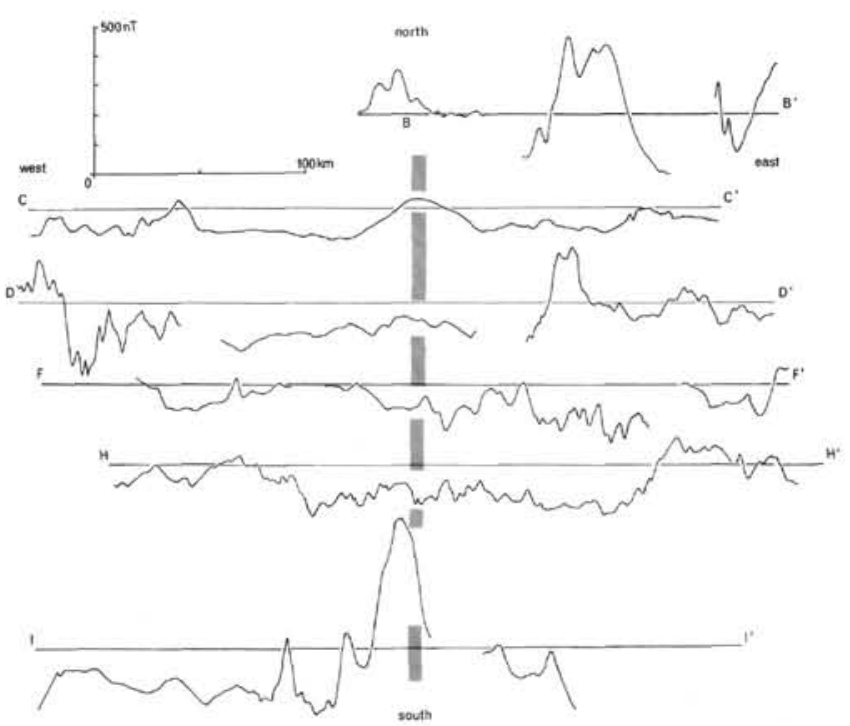

Figure 16. Magnetic anomaly profiles across the western gravity high. The vertical stripe marks the position of the maximum gravity value (location, Figure 10a).

occurs over a basement high. Seismic data show that the shallow basement has a seismic velocity of $6.0 \mathrm{~km} / \mathrm{sec}$ in 

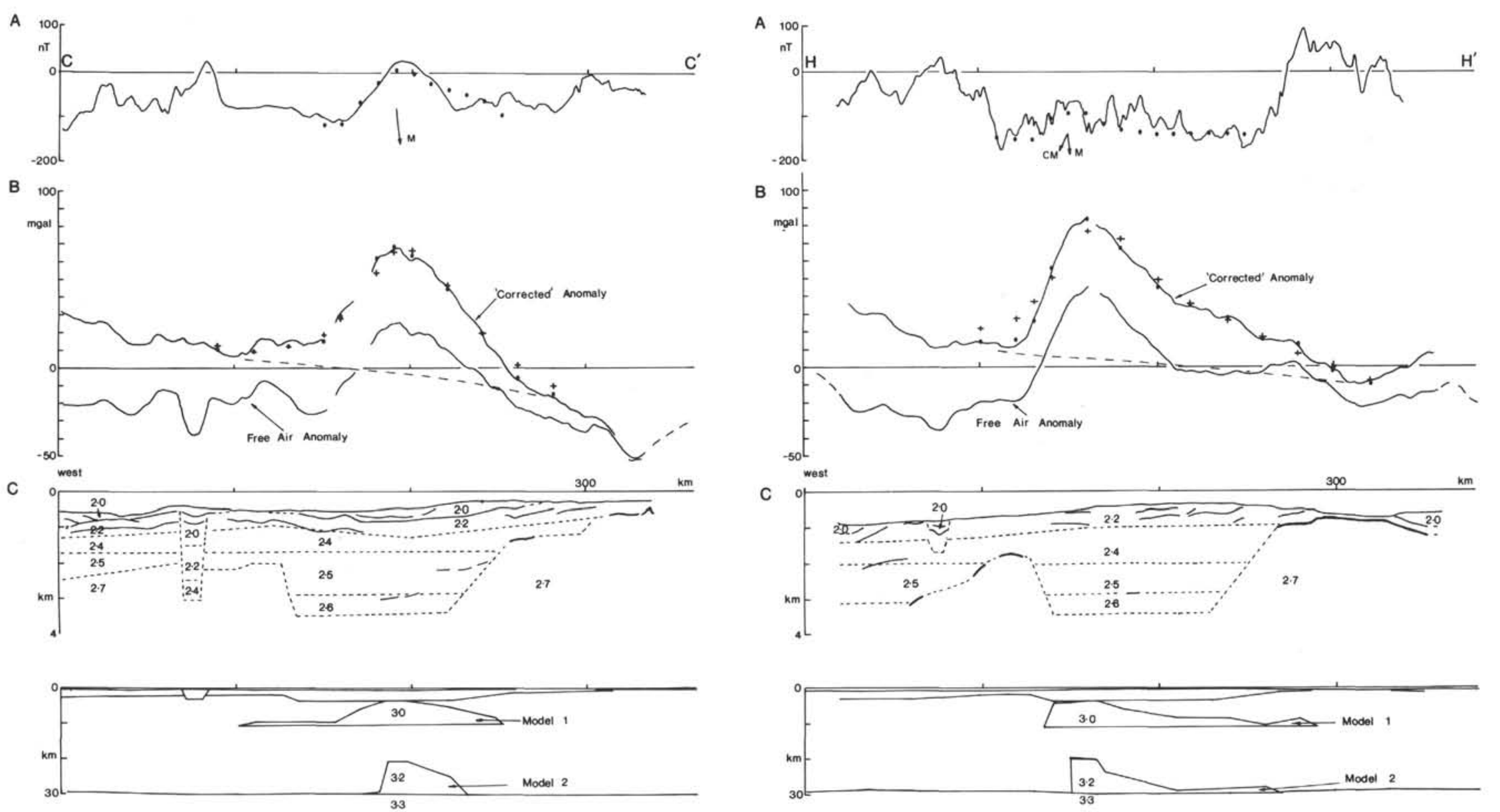

Figure 17. Geophysical data and interpreted models for profiles CC' and HH'. A shows the observed magnetic anomaly with the computed anomaly for the shallow intrabasement model (1) shown by solid circles. B shows the observed free-air gravity anomaly and the isostatic anomaly corrected for the sedimentary model. The computed "corrected" anomaly for the shallow intrabasement body, model 1, is shown by solid circles and that for the deep body, model 2, by crosses. C shows the bathymetric and seismic data with basement, seismic velocity $>5.0 \mathrm{~km} / \mathrm{sec}$, marked by heavy lines. The assumed sedimentary model is shown by dashed lines with assumed densities given in $\mathrm{Mg} / \mathrm{m}^{3}$. Beneath is the crustal model showing the alternative high-density bodies which could give rise to the gravity high (location, Figure 10a). 
this region thus implying that the source of the negative anomaly cannot be low-density sediments. In view of the widespread occurrence of acidic intrusives in both Victoria Land and Marie Byrd Land, we tentatively interpret this anomaly as being partially caused by a granitic intrusion. Bennett (1964) has postulated a granite as the source of the gravity minimum at Roosevelt Island $\left(79^{\circ} \mathrm{S}, 163^{\circ} \mathrm{W}\right)$.

Profile $\mathrm{CC}^{\prime}$ shows a short wavelength free-air gravity low to the west of the main positive anomaly. This gravity low is interpreted as being caused by a graben feature about $2 \mathrm{~km}$ deep and containing low-density sediments. The seismic profiler data, Figure 17, show downwarped sediments over this feature, and the $3.5-\mathrm{kHz}$ bathymetric data show a series of distinct point reflectors ("boulder clay") in an acoustically transparent mud. Profile $\mathrm{HH}^{\prime}$ shows a similar gravity feature, although with a smaller amplitude, and a similar interpretation has been assumed. If these graben features represent a continuous structure, then its inferred north-south alignment is parallel to the main positive anomaly.

At the northwest end of the Ross Sea shelf are two large magnetic anomalies, "a" in Figure 13. Profile LL' crosses these anomalies which show no apparent relation with any structures on the seismic profiler data thus suggesting that the source of the large magnetic anomalies must lie at depths below the seismic penetration $(>500 \mathrm{~m})$. Coulman Island is formed of Cenozoic volcanics of the McMurdo Volcanics Group and lies close to these large magnetic anomalies; therefore basic intrusives, related to this volcanic group, are proposed as the source of these anomalies. No model fitting has been done as the anomalies are apparently not twodimensional, and insufficient data exist for a meaningful three-dimensional interpretation to be carried out.

\section{Eastern Ross Sea Shelf}

The eastern Ross Sea shelf is marked by the lack of any significant magnetic anomaly and only one gravity anomaly of limited extent. Profile KK' (Figure 18) is a projected profile which is aligned roughly west to east across the eastern Ross Sea shelf (Figure 10a). The gravity anomaly shows no major variation corresponding to the sediment thickness variations deduced from seismic information by Houtz and Davey (1973). The isostatic anomaly shows a mean value of about -20 mgal, the same as that over the rest of the Ross Sea shelf. A crustal density of $2.7 \mathrm{Mg} / \mathrm{m}^{3}$, a crust-mantle density contrast of $0.6 \mathrm{Mg} / \mathrm{m}^{3}$, and a standard crustal thickness of $30 \mathrm{~km}$ were used for the isostatic anomaly calculations. At the eastern end of profile $\mathrm{KK}^{\prime}$ the gravity anomaly decreases to a localized low with a relative amplitude of about $20 \mathrm{mgal}$. Seismic profiler data over this anomaly show evidence for a ridge or dome structure in the sediments (Houtz and Davey, 1973, fig. 11, profile $\left.L^{\prime}\right)$. No significant magnetic anomaly is associated with the gravity anomaly. We suggest, therefore, that the gravity anomaly is caused by an acidic intrusive, similar to those occurring in the adjacent Marie Byrd Land, and that the sediments seen on the profiler records have been uplifted by the emplacement of the instrusion or have been deposited over the uplifted intrusive. The dips of the reflectors are low $\left(\sim 1^{\circ}\right)$ and could result from differential compaction. If the sediments have been distorted by the postulated intrusion and if this intrusion is of the same general age as those in Marie Byrd Land (100 m.y., Wade and Wilbanks, 1972), then these sediments must be Cretaceous or older. We prefer the interpretation that these sediments were deposited after the postulated granite was emplaced in view of the post Oligocene ages of the sediments found in the same basin by drilling (Hayes et al., 1973; Hayes and Frakes, this volume). Alternatively, the postulated granite intrusion could be much younger than Cretaceous.

\section{Continental Rise}

Two geophysical profiles, $\mathrm{LL}^{\prime}$ and $\mathrm{MM}^{\prime}$, across the shelf, slope, and rise of the Ross Sea are shown in Figure 19. One profile passes to the west of Iselin Bank (profile $L^{\prime}$ ) and the other to the east of Iselin Bank.

\section{Iselin Bank}

Three geophysical profiles, $\mathrm{NN}^{\prime}, \mathrm{OO}^{\prime}$ and $\mathrm{PP}^{\prime}$, across Iselin Bank showing bathymetric, seismic profiler; gravity and magnetic data are given in Figure 20. A course alteration occurs on profile $\mathrm{OO}^{\prime}$. The seismic data with the bathymetric data indicate an asymmetric crosssection to the main part of the bank. The western slope shows steps or benches in the basement which are sediment filled, whereas the basement underlying the eastern slope has a smoother outline and is overlain by a prograded wedge of sediments. This prograded wedge of sediments onlap basement to the west and may indicate a sinking of the bank. In the southern profile, profile $\mathrm{NN}^{\prime}$, acoustic basement outcrops over the central part of the bank. Further to the north, in profile $\mathrm{OO}^{\prime}$, the central part of the bank is covered by up to 300 meters of sediments, and as the profiler record is confined to the top of the bank, the prograded wedge of sediments to the east is not recorded here. Towards the west the bank is split by a trough containing at least $1 \mathrm{~km}$ of layered sediments which show two major reflectors and a possible basement reflector. The upper reflectors in the trough dip to the west and outcrop in the east. At the western edge of the trough there is a sharp reversal in the dip of the reflectors which probably indicates recent faulting or diapirism. We suggest that the trough was formed by hinge faulting with the major fault marking the western boundary of the trough. Piercement structures are seen on the bank to the west of this trough. The reflection data over profile PP' $^{\prime}$ are poor in quality, but indicate thin sediment cover over the western branch of the bank.

Free-air gravity anomalies are shown for profiles $\mathrm{NN}^{\prime}$ and $\mathrm{OO}^{\prime}$. No gravity data are available for profile $\mathrm{PP}^{\prime}$. A local Airy isostatic anomaly is shown for profile $\mathrm{NN}^{\prime}$ based on the same crustal parameters used in the previous section. The average isostatic anomaly is about $-20 \mathrm{mgal}$ and is close to that for the entire Ross Sea shelf. Large departures from this mean anomaly value occur west of the bank and over the eastern part of the bank and coincide with large thicknesses of sediments. 


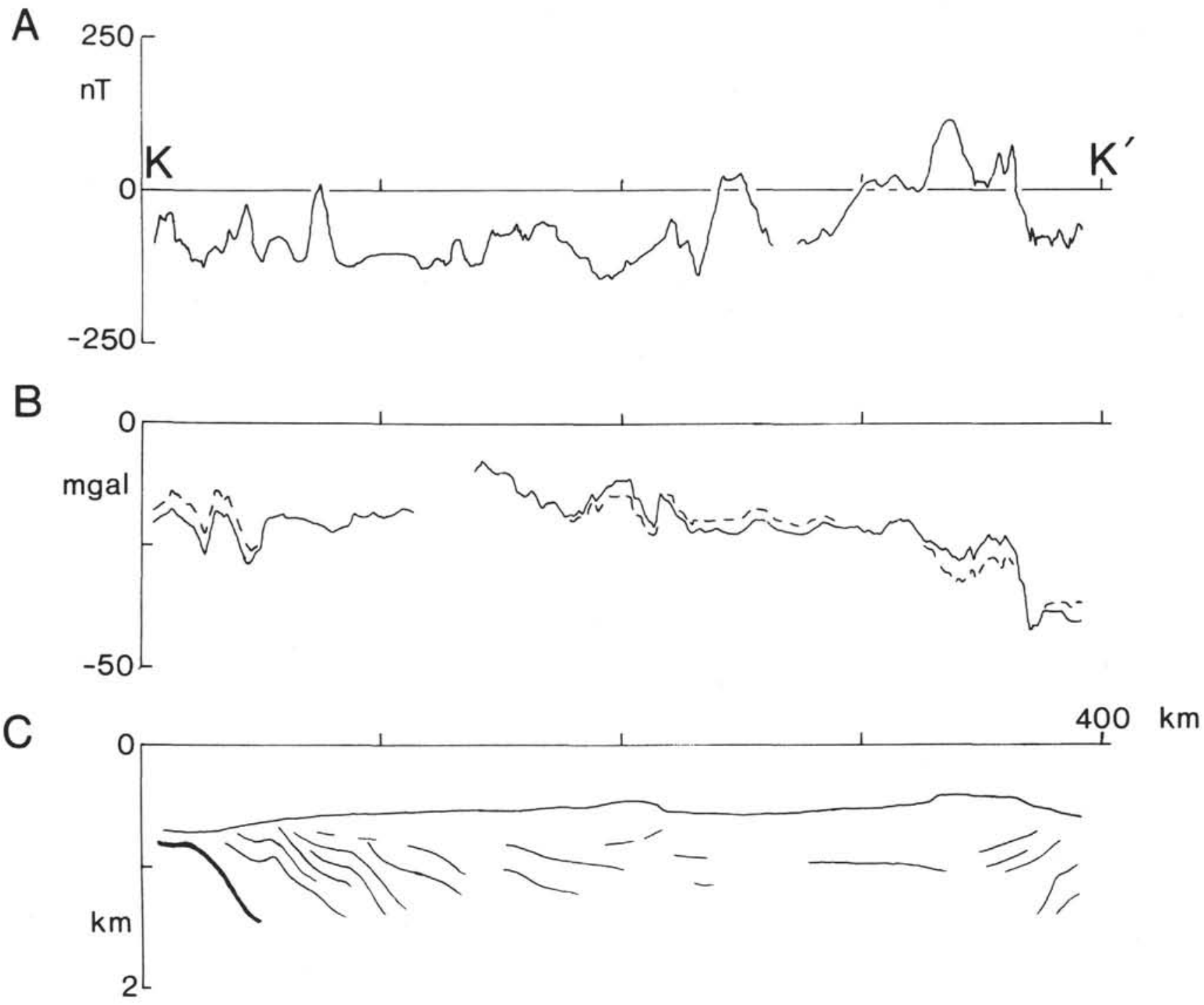

Figure 18. Geophysical data along profile KK' across the eastern Ross Sea shelf. A shows the observed magnetic anomaly. $B$ shows the observed free-air gravity anomaly (solid line) and the isostatic anomaly (dashed line). C shows the bathymetry and interpreted seismic data; basement, seismic velocity $>5.0 \mathrm{~km} / \mathrm{sec}$, is marked by the heavy line (location, Figure 10a).

Corrections were made for the sediments assuming density contrasts with basement of $0.7 \mathrm{Mg} / \mathrm{m}^{3}$ and 0.3 $\mathrm{Mg} / \mathrm{m}^{3}$, as shown in Figure 20 . The mean "corrected" isostatic anomaly is then found to be about $-15 \mathrm{mgal}$. The gravity field over profile $\mathrm{OO}^{\prime}$ is generally similar to that over profile $\mathrm{NN}^{\prime}$ apart from the gravity low corresponding to the sediment filled trough on profile $\mathrm{OO}^{\prime}$ The magnetic measurements show short wavelength, low amplitude anomalies over shallow basement on both profiles $\mathrm{NN}^{\prime}$ and $\mathrm{OO}^{\prime}$ that are generally characteristic of continental regions. One exception is the large positive magnetic anomaly of over $500 \mathrm{nT}$ amplitude which marks the eastern edge of the northwestern arm of the bank, as seen on profiles $\mathrm{OO}^{\prime}$ and $\mathrm{PP}^{\prime}$. This large anomaly also coincides with the western edge of the trough on profile $\mathrm{OO}^{\prime}$ where possible intrusive structures are seen on the profiler data. The anomaly is too asymmetric to assume that the whole western branch is uniformly magnetized, even at a low angle of dip, and no anomaly is seen over the southwest edge of the bank. We presume that the magnetic anomaly is caused by highly magnetic basic intrusives confined only to the eastern part of the branch.

Northwest of the bank on profile $\mathrm{NN}^{\prime}$ intrusive features are also seen on the profiler data. The westernmost one occurs as a topographic high and forms part of an east-west ridge that dams the flow of sediments from the Ross Sea shelf (Houtz and Davey, 1973). Distinctive gravity and magnetic anomalies are associated with these features, and the gravity calculations carried out for this profile indicated a density of at least $2.6 \mathrm{Mg} / \mathrm{m}^{3}$ for the rocks forming these intrusives. A simple twodimensional model has been fitted to the magnetic anomaly over these features. The upper surface of the 
A 1000

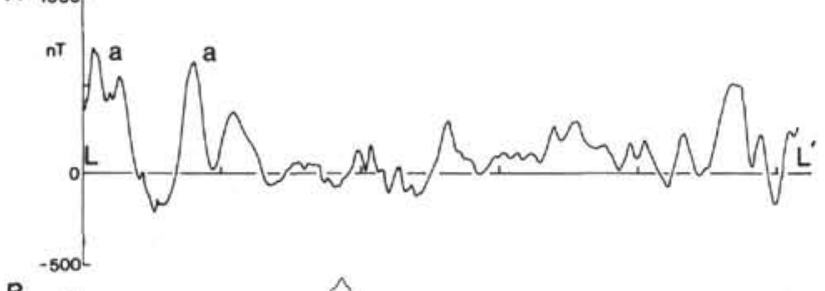

B

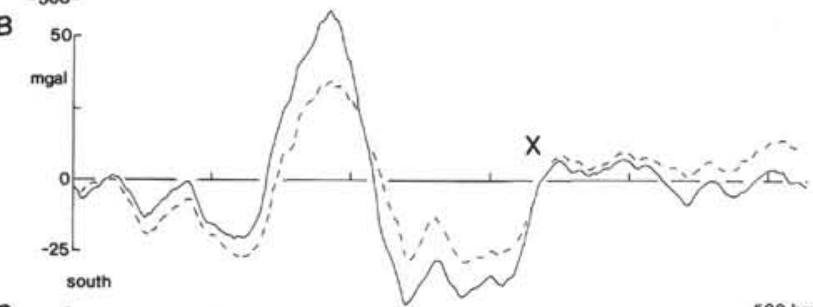

C

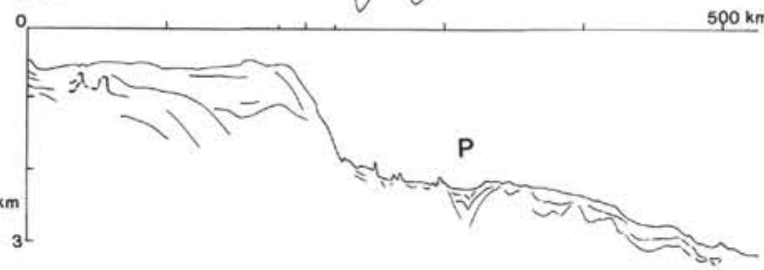

A 500

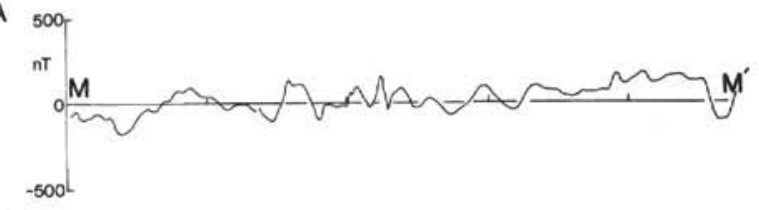

B

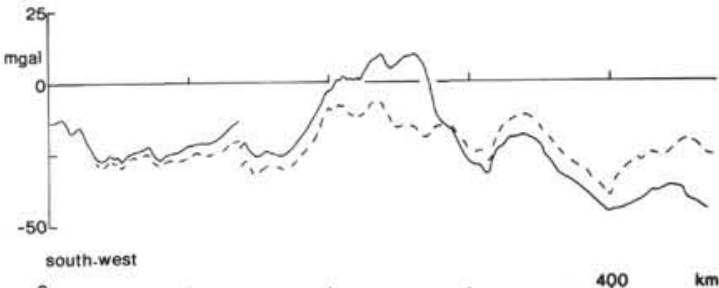

c

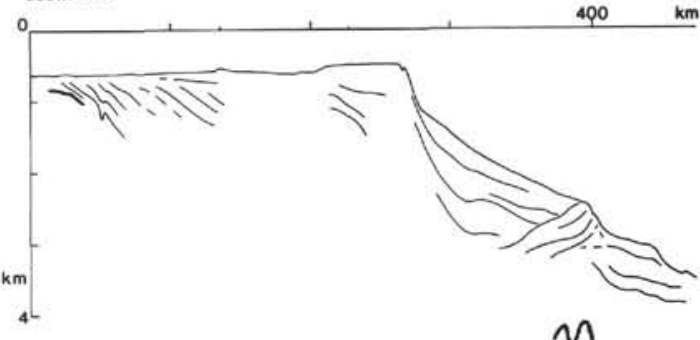

Figure 19. Geophysical data along profile LL' and MM'. Details as for Figure 18. Basement seismic velocity is $>4.5 \mathrm{~km} / \mathrm{sec}$ off the shelf. " $a$ " corresponds to the anomalies " $a$ " in Figure 13. $X$ and P are positions referred to in text (location, Figure $10 a)$.
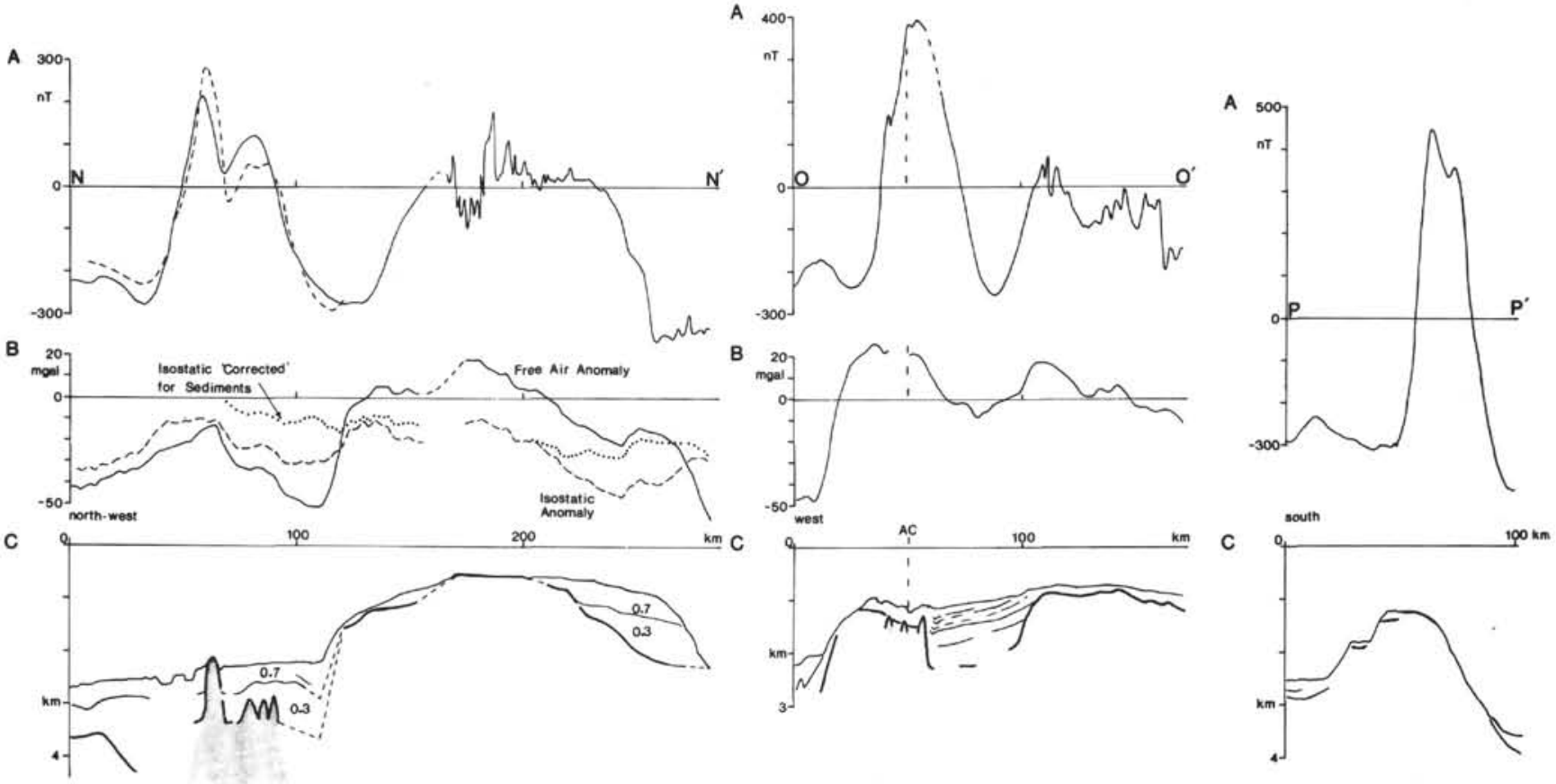

${ }_{C M} A_{M}$

Figure 20. Geophysical data across Iselin Bank. Details as for Figure 18. Profile NN'also shows the computed magnetic anomaly (dashed) for the model shown shaded in $C$, and the isostatic anomaly (dashed) and the isostatic anomaly corrected for the low-density sediments (dotted). The sediments are shown with their density contrasts $\left(\mathrm{Mg} / \mathrm{m}^{3}\right)$ in $\mathrm{C}$. AC on profile OO' marks a course alteration (location, Figure 13.) 
model was assumed to be that shown by acoustic basement and its horizontal extent limited as shown by the shading in Figure 20. It was assumed to extend to a depth of $8 \mathrm{~km}$ and be homogeneously magnetized. The computed anomaly shown in Figure 20 and corresponding to a magnetization of $2.7 \mathrm{~A} \mathrm{~m}^{-1}$ dipping at $67^{\circ}$ in the plane of the profile fits the observations well. Bearing in mind the assumptions made, this model taken together with the gravity results indicates that the intrusives are probably basic igneous rocks.

\section{SUMMARY}

The results of the gravity, magnetic, and bathymetric surveys of the Ross Sea shelf show similar gross features to those presented by Bennett (1964) for the Ross Ice shelf, thus indicating a continuity of structure over this topographically depressed region-a not unexpected result. Gravity measurements indicate that the shelf is slightly undercompensated isostatically, with a mean free-air anomaly of $-12.9 \mathrm{mgal}$ (mean isostatic anomaly of about -20 mgal). Bennett (1964) attributed this and the unusually great depth of the continental shelf to depression of the shelf by a former ice load which has since been removed. This explanation is by no means certain because, as Houtz and Meijer (1970) note, although there are erosional features on the shelf which apparently resulted from a grounded ice sheet, other marginal plateaus, such as the Campbell Plateau, lie at similar depths but have definitely not been ice covered in recent times. The effects of some ice loading cannot be ignored, particularly since the depth of the entire Antarctic continental shelf lies uniformly at about 500 meters. However, it is also possible that the anomalous shelf depth results in part from regional tectonics, especially as the area forms the boundary between two geologically different subcontinents.

A comparison of the magnetic anomaly map and the gravity anomaly map shows that there is a general lack of correlation between the main magnetic and gravity anomalies, thus suggesting different geologic sources for anomaly fields, a result also noted by Bennett (1964) for his data over the Ross Ice Shelf.

The most striking feature seen in the geophysical data is the linear positive gravity anomaly trending northsouth across the western Ross Sea and northern Ross Ice Shelf. Although this feature may terminate at about $80^{\circ} \mathrm{S}$, we consider that alternatively it may swing to the southeast at this position and parallel the Transantarctic Mountains, Figure 21. When considered with the available seismic data, the unusual coincidence of a large positive gravity anomaly with thick, low-density sediments and a negative gravity anomaly with shallow basement is apparent.

The dimensions and amplitude of this anomaly suggest a similarity to the mid-continental gravity high of the central United States (Coons et al., 1967). The mid-continental gravity high has an amplitude of up to about $140 \mathrm{mgal}$, a wavelength of about 50 to $60 \mathrm{~km}$, and can be traced for about $1200 \mathrm{~km}$ through the central United States in a northeast-southwest direction. The structure underlying the northern part of the midcontinental gravity high has been derived from seismic

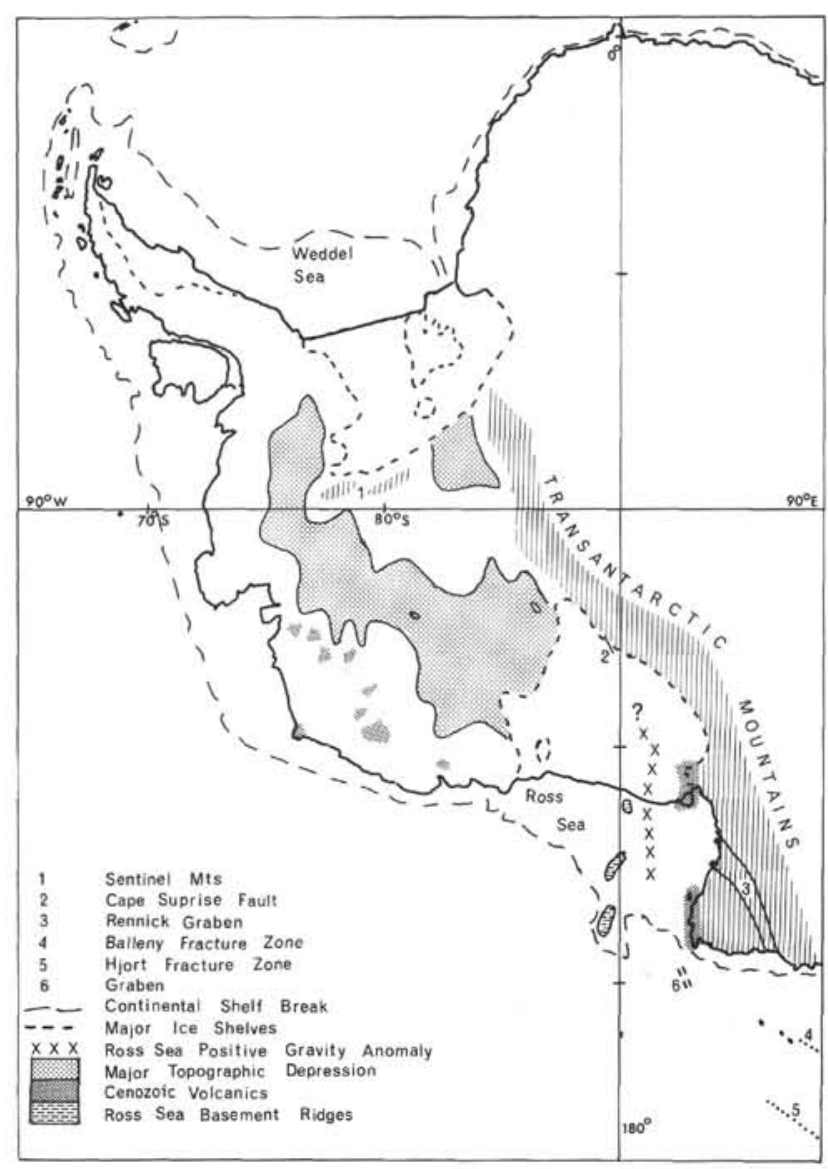

Figure 21. The major structures underlying the Ross Sea and their relation to structural features in the vicinity.

data by Mooney et al. (1970). Their data show an uplifted block or horst of late Precambrian mafic volcanics and gabbros associated with flanking basins containing younger Precambrian sedimentary rocks. To the south these rocks dip under Paleozoic sedimentary rocks. McGinnis (1970) and Chase and Gilmer (1973) consider that the structure causing the mid-continental gravity high resulted from crustal rifting, possibly a short-lived spreading center, which gave rise to the emplacement of intrusives and extrusives along the line of the gravity high. Cohen and Meyer (1966), Coons et al. (1967), and McGinnis (1970) have noted that the mid-continental gravity high lies along the axis of a broad syncline and postulated that it was formed by the isostatic response of the crust to the imposed load of the high-density body causing the gravity high. Presumably subsequent faulting occurred along the edges of the original rift to give the observed horst.

Our shallow model, model 1, but for the lack of an equivalent of the extrusives, as indicated by the lack of any major magnetic anomaly associated with the Ross Sea gravity anomaly, and any subsequent faulting, may represent a loading situation similar to the midcontinental gravity high. The density contrast used in our model (Figure 17), however, is more consistent with the high-density body being formed by a basic intrusive. 
Intrusives would be expected to have lower magnetizations than their corresponding extrusives and the magnetizations derived using the models in Figure 17 are consistent with typical values for basic intrusives. The inferred high-density body is relatively deep in the crust and our model could be adjusted to include a thin "extrusive" layer along its upper surface, especially if intercalated sedimentary units are included as Chase and Gilmer (1973) do in their model, and still give only a relatively small magnetic anomaly. The postulated isostatic downwarping of the crust in the region of a rift can also be invoked to account for the origin of the sedimentary basin occurring over the high-density body in the Ross Sea, but it would not account for the overall depression of the sea floor underlying the Ross Sea and Ross Ice Shelf. If this general mechanism is correct, then the gravity anomaly may mark the position of a former, short-lived, spreading center or leaky transform boundary and may, therefore, have resulted from crustal movements associated with the separation of Australia, Antarctica, and New Zealand.

Other gravity anomalies which have similarities with the Ross Sea anomaly include the Ivrea Anomaly (Mueller and Talwani, 1971) and the large anomalies on the Norwegian continental shelf (Talwani and Eldholm, 1972). The former differs from the Ross Sea anomaly in its close association with a major orogenic belt, the Alps, whereas the Ross Sea anomaly has no apparent close association with the Transantarctic Mountains. The Norwegian shelf anomaly, like the Ross Sea anomaly, occurs over a thick sequence of sediments, but it is much shorter in wavelength and is closely associated with a large magnetic anomaly. Talwani and Eldholm (1972) postulate that it is caused by intrabasement highdensity bodies of Precambrian age, probably granulite and amphibolite facies rocks. We cannot discount the possibility that the Ross Sea anomaly is due to rocks of similar type.

We prefer the rift and intrusive model because of the lack of a magnetic anomaly and the similarity of the dimensions of the anomaly and the model with other rift structures. The upper sediments of the sedimentary trough underlying the Ross Sea gravity anomaly are fairly smooth, flat-lying sediments, thus indicating that the rifting associated with the postulated intrusion and subsequent downwarp of the basement rocks is considerably older than the upper 500 meters of sediments, early Miocene from Glomar Challenger data (Hayes and Frakes et al., this volume) and has not undergone any movement in recent times. The small-scale graben to the west of the main positive anomaly, on the contrary, has been active in recent times as is demonstrated by the downwarp of the upper sediments on the seismic reflection records (Figure 17). These rift features indicate an approximately east-west extension in the crust which is also reflected by the graben seen on the Ross Sea continental rise to the north and the Rennick Graben (Kyle and Cole, in press) in northern Victoria Land, Figure 21.

The sedimentary basin underlying the eastern Ross Sea shelf is not marked by a residual gravity low thus indicating the lack of low-density sediments. A possible explanation for this lack of a negative gravity anomaly would involve a mode of origin invoking downwarping, deposition and compaction followed by uplift and erosion of the near surface, low-density sediments. The compacted nature of the sea-floor sediments is supported by the high near sea-floor seismic velocity found by Houtz and Davey (1973) and the hard sea-floor drilling conditions experienced by Glomar Challenger (Chapter 8, this volume, Physical Properties section).

The large positive gravity and magnetic anomalies which occur together at the junction of Iselin Bank with the western Ross Sea continental shelf are probably due to a different source than the linear positive gravity anomaly to the southwest. Seismic reflection data indicate that basement is fairly close to the sea floor, and we interpret these data as indicating the existence of a basic igneous center. We also attribute the other magnetic anomalies, "c," "d," and "e" in Figure 13, to a similar source. These igneous bodies may be related to the Cenozoic volcanics seen along the western margin of the Ross Sea, but their position suggests a generic association with the Iselin Bank-Ross Sea shelf junction. The western Ross Sea and the western Iselin Bank margins have a block-faulted appearance. This, together with the existence of a number of roughly north-southtrending ridges on the western Ross Sea rise, may be indicative of rifting between the Iselin Bank and the western Ross Sea. This rifting may involve some differential movement between the Ross Sea shelf and Iselin Bank thus giving rise to the igneous centers at the western junction of the two and to the southeast. If this movement occurred following the separation of Australia and New Zealand from Antarctica, then these igneous centers would be Cretaceous to early Tertiary in age.

The continental margin can be considered in light of the work of Talwani and Eldholm (1973) on the margins of rifted continents. For the area west of Iselin Bank the interpretation of the geophysical data is complicated by the existence of many ridges and seamounts. The gravity profile across this region, profile $\mathrm{LL}^{\prime}$ ' in Figure 19, can be interpreted as indicating a "continental margin" near $X$. However, the magnetic data do not show a distinct change in character at this location, and the geophysical parameters are probably affected by the graben structure which lies close to the profile at this point.

To the east of Iselin Bank the structure of the margin is apparently simpler, although this may result from a lack of data. The magnetic anomalies there are small, profile $\mathbf{M M}^{\prime}$ in Figure 19, and suggest that oceanic crust lies further seaward than the profile extends. There is also no distinctive change in the isostatic gravity anomaly. The seismic data show a step down in basement under the continental slope at $400 \mathrm{~km}$ on profile MM', $^{\prime}$, Figure 19, and this has been interpreted by Houtz and Davey (1973) as possibly marking the ancient rift formed during the separation of the New Zealand Plateau from Antarctica. The thick sediments on the ocean side of the step suggests that the continental boundary lies to the north of the profile, an interpretation consistent with the gravity and magnetic data. 


\section{CONCLUSIONS}

The Ross Sea shelf forms part of a topographic depression marking the junction of eastern and western Antarctica. On the basis of new bathymetric and gravity data and published seismic data, the shelf may be divided into two parts. The western Ross Sea shelf, west of $180^{\circ}$, is marked by a higher topographic relief than the eastern Ross Sea shelf and shows a northeast-southwest grain whereas the morphology of the eastern Ross Sea shelf is dominantly north-south. The western shelf is marked by a number of prominent gravity anomalies in contrast to the eastern shelf which is, gravitationally, relatively flat. Significant magnetic anomalies are rare throughout the entire Ross Sea shelf region.

The gravity data show a large, linear positive anomaly trending north-south across the western Ross Sea shelf. There are some similarities between the Ross Sea gravity high and the mid-continental gravity high of the United States. We interpret this anomaly as due to a highdensity body underlying a sedimentary trough and suggest that the high-density body may be a basic intrusive resulting from minor rifting between East and West Antarctica. The rifting may mark an ancient zone of mantle upwelling and hence the position of a shortlived spreading center. It may also be related to the rift or fault-block structures seen at the western Ross Sea and Iselin Bank margins. More recent evidence for eastwest extension is found in the minor graben structures to the west of Ross Sea gravity high and perhaps in the Rennick Graben in Victoria Land. We can add no evidence to the case for, or against, a fault-block structure for the Transantarctic Mountains.

We interpret two gravity lows as being caused by granitic intrusions whose age remains open to question. One, the gravity low at the eastern margin of the Ross Sea shelf, may well be caused by a granitic intrusion of Cretaceous age from the association with the granite intrusions in Marie Byrd Land (Wade and Wilbanks, 1972). The other gravity low, at $74^{\circ} \mathrm{S} 180^{\circ}$, coincides with the basement rise trending along $180^{\circ}$. DSDP Site 270 reached basement at the south end of this ridge, near the ice shelf, and cored a calcareous gneiss (Ford and Barrett, this volume). This gneiss may be correlatable with the calcareous metasedimentary rocks of southern Victoria Land of early Paleozoic age. In Victoria Land the calcareous metasediments form an anticlinorium with an acidic batholith of Ordovician age at its core (Lopatin, 1972). This suggests a possible lower Paleozoic age for the postulated granite and may imply a continuity or connection between the basement rocks from the Transantarctic Mountains and those of the central Ross Sea.

From our data we can see no strong evidence for or against a transcurrent movement in the Ross Sea parallel to the Transantarctic Mountains. If such a movement occurred, two possibilities for the position of this transcurrent movement seem plausible. These are either close to the topographic deep of the east Victoria Land coast or along the line of Ross Sea gravity high. In the latter case small elements of transcurrent and exten- sional motion may be operating in concert as has been suggested for the Macquarie Ridge complex (Hayes and Talwani, 1972).

The available geophysical data indicate that Iselin Bank is probably continental in structure. Sediments showing horizontal layering form the eastern slope of the bank and onlap basement to the west indicating possible submergence of the bank. The north end of the bank is split by a northerly trending trough presumably formed by a hingefault block and filled by flat-lying sediments. The branch of the bank to the northwest of this trough is marked by a large positive magnetic anomaly over its northeastern flank and continues as a morphological ridge for an additional $130 \mathrm{~km}$, curving around to trend in a northwest direction. The diapir-like reflections seen on the profiler records to the west of the bank are probably caused by basin intrusives.

\section{ACKNOWLEDGMENTS}

We are indebted to the officers and crew of USNS Eltanin and to the Lamont-Doherty Geological Observatory geophysics personnel aboard during the Ross Sea cruises. This paper was reviewed by T. Hatherton, R. Houtz, and T. Watts, who provided valuable comments and suggestions. M. Talwani collaborated in the initial phases of discussion regarding the Ross Sea gravity high. P. Gill kindly provided the geomagnetic data for Scott base. General access to unpublished Lamont-Doherty Geological Observatory gravity and magnetic data is gratefully acknowledged. The shipboard programs and research were supported primarily by the Office of Polar Programs of the National Science Foundation (Grants GV-27472, GV-40896) although the Division of Environmental Sciences of the National Science Foundation (Grant GA27281) and the Office of Naval Research (Contract N0001467-A-0108-0004) provided partial support for one author (DEH).

\section{REFERENCES}

Adams, R.D. and Christoffel, D.A., 1962. Total magnetic field surveys between New Zealand and the Ross Sea: J. Geophys. Res., v. 67, p. 805-813.

Adie, R.J., 1962. The geology of Antarctica: Am. Geophys. Union, Geophys. Mon. 7, p. 26-39.

American Geographical Society, 1970. Map of Antarctica, 1:5,000,000: Washington (American Geographical Society).

Bennett, H.F., 1964. A gravity and magnetic survey of the Ross Ice Shelf, Antarctica: Univ. Wisconsin, Geophys. Polar Res. Cent., Res. Rep. 64-3.

Bentley, C.R. and Ostenso, N.A., 1962. On the paper of F.F. Evison, C.E. Ingham, R.H. Orr and J.H. Lefort, Thickness of the earth's crust in Antarctica and the surrounding oceans: Geophys. J., v. 6, p. 292-298.

Cartwright, D.E. and Stride, A.H., 1958. Large sandwaves near the edge of the continental shelf: Nature,v. 181, p. 41.

Chase, C.G. and Gilmer, T.H., 1973. Precambrian plate tectonics: The mid-continental gravity high: Earth Planet. Sci. Lett., v. 21 , p. $70-78$.

Christoffel, D.A. and Falconer, R.K., 1973. Changes in the direction of seafloor spreading in the southwest Pacific. In 
Fraser, R. (Ed.), South Pacific Oceanography, 1972: Wellington, (Nat. Comm. for UNESCO), p. 241248.

Cohen, T.J. and Meyer, R.P., 1966. The midcontinent gravity high; gross crustal structure: The earth beneath the continents, Geophys. Monogr. 10, p. 141-165: Washington (Am. Geophys. Union).

Coons, R., Woollard, G.P., and Hershey, H.G., 1967. Structural significance and analysis of the midcontinental gravity high: Am. Assoc. Petrol. Geol. Bull., v. 51, p. 2381-2399.

Crary, A.P., Robinson, E.S., Bennett, H.F., and Boyd, W.W., 1962. Glaciological studies of the Ross Ice Shelf, Antarctica, 1957-60: IGY Glaciol. Rept. 6, Am. Geog. Soc.

Cullen, D.J., 1968. Movement of sialic blocks oblique to the direction of seafloor spreading: Earth Planet. Sci. Lett., v. 5, p. 123-126.

David, T.W.E. and Priestley, R.E., 1914. Glaciology, physiography, stratigraphy and tectonic geology of South Victoria Land: Brit. Antarctic Exped. 1907-09, Geol., v. 1.

Evison, F.F., Ingham, C.E., Orr, R.H., and Lefort, J.H., 1960. Thickness of the earth's crust in Antarctica and the surrounding oceans: Geophys. J., v. 3, p. 289-306.

Gunn, B.M., 1963. Geological structure and stratigraphic correlation in Antarctica: New Zealand J. Geol. Geophys., v. 6, p. 423-443.

Hamilton, W., 1967. Tectonics of Antarctica: Tectonophysics, v. 4 , p. $555-568$.

Harrington, H.J., Wood, B.L., McKellar, I.C., and Lensen, G.S., 1967. Topography and geology of the Cape Hallett district, Victoria Land, Antarctica: Geol. Surv. New Zealand Bull., n.s. 80.

Hayes, D.E. and Ringis, J., 1973. Seafloor spreading in the Tasman Sea: Nature, v. 243, p. 454-458.

Hayes, D.E. and Talwani, M. 1972. A geophysical study of the Macquarie-Ridge-complex. In Hayes, D.E. (Ed.), Antarctic Oceanology II: the Australian-New Zealand Sector: Antarctic Res. Ser., v. 19: Washington (Am. Geophys. Union), p. 211-234.

Hayes, D.E., Frakes, L.A., Barrett, P., Burns, D.A., Chen, P., Ford, A.B., Kaneps, A.G., Kemp, E.M., McCollum, D.W., Piper, D.J.W., Wall, R.E., and Webb, P.N., 1973. Leg 28 deep-sea drilling in the southern ocean: Geotimes, v. 18, p. $19-24$.

Houtz, R. and Davey, F.J., 1973. Scientific profiler and sonobuoy measurements in Ross Sea, Antarctica: J. Geophys. Res., v. 78, p. 3448-3468.

Houtz, R.E. and Meijer, R., 1970. Structure of the Ross Sea shelf from profiler data: J. Geophys. Res., v. 75, p. $6592-$ 6597.

IAGA Commission 2 Working Group 4, 1969. Analysis of the geomagnetic field, International Geomagnetic Reference Field 1965.0: J. Geophys. Res., v. 74, p. 4407-8.

Jacobs, S.S., Amos, A.F., and Bruckhausen, P.M., 1970. Ross Sea oceanography and Antarctic Bottom Water formation: Deep Sea. Res., v. 17, p. 935-962.

King, B.C., 1965. Geological relationships between South Africa and Antarctica: Geol. Soc. South Africa: A. Du Toit Mem. Lecture 9.

Kovach, R.L. and Press, F., 1961. Surface wave dispension and crustal structure in Antarctica and the surrounding oceans: Ann. Geofis., v. 4, p. 211-224.
Kyle, P.R. and Cole, J.W., in press. Structural control of volcanism in the McMurdo Volcanic Province, Antarctica: Bull. Volcanol. 38.

Langhorne, D.N., 1973. A sandwave field in the outer Thames Estuary, Great Britain: Marine Geol., v. 14, p. 129-143.

Lopatin, B.G., 1972. Basement complex of the McMurdo "oasis," south Victoria Land. In Adie, R.J. (Ed.), Antarctic Geology and Geophysics: Oslo (Universitets forlaget), p. 287-292.

Matthews, D., 1939. Tables of the velocity of sound in pure water and sea water) London (Hydrographic Dept., Admiralty).

McGinnis, L.D., 1970. Tectonics and the gravity field in the continental interior: J. Geophys. Res., v. 75, p. 317-331.

Mooney, H., Craddock, C., Farnham, P.R., Johnson, S.H., and Volz, G., 1970. Refraction seismic investigations of the northern midcontinent gravity high: J. Geophys. Res., 75, p. 5056-5086.

Mueller, S. and Talwani, M., 1971. A crustal section across the Eastern Alps: Pure Appl. Geophys., v. 85, p. 226-239.

Nagata, T., 1962. Morphology and some interpretation of geomagnetic variations in Antarctica: Am. Geophys. Union, Geophys. Mono. 7, p. 89-110.

Ostenso, N.A. and Thiel, E.C., 1964. Aeromagnetic reconnaissance of Antarctica between Byrd and Wilkes stations: Univ. of Wisconsin, Geophys. Polar Res. Cent., Res. Rept. 64-6.

Penndorf, R., 1965. The average ionospheric conditions over the Antarctic. In Waynick, A.H. (Ed.), Geomagnetism and Aeronomy, Antarctic Res. Ser., v. 4: Washington (Am. Geophys. Union), p. 1-46.

Rikitake, T., 1966. Electromagnetism and the Earth's interior: Amsterdam (Elsevier Publishing Co.).

Robinson, E.S., 1963. Geophysical investigations in McMurdo Sound, Antarctica: J. Geophys. Res., v. 68, p. 257-262. 1964. Regional geology and crustal thickness in the Transantarctic Mountains and adjacent ice covered areas in Antarctica: Geol. Soc. Am., Special paper 76.

Roden, R.B., 1963. The effect of an ocean on magnetic diurnal variations: Geophys. J., v. 8, p. 375-388.

Talwani, M. and Eldholm, O., 1973. The boundary between continental and oceanic crust at the margins of rifted continents: Nature, v. 241 , p. $325-330$.

1972. The continental margin off Norway: a geophysical study: Geol. Soc. Am. Bull., v. 83, p. 35753606.

Talwani, M., Sutton, G.H., and Worzel, J.L., 1959. A crustal section across the Puerto Rico Trench: J. Geophys. Res., v. 64 , p. $1545-1555$.

Van der Linden, W.J.N., 1967. Structural relationships in the Tasman Sea and S.W. Pacific Ocean: New Zealand J. Geol. Geophys., v. 10, p. 1280-1301.

Wade, F.A. and Wilbanks, J.R., 1972. Geology of Marie Byrd and Ellsworth Lands. In Adie, R.J. (Ed.), Antarctic Geology and Geophysics: Oslo (Universitets forlaget), p. 207-214.

Weissel, J.K. and Hayes, D.E., 1972. Magnetic anomalies in the south eastern Indian Ocean. In Hayes, D.E. (Ed.), Antarctic Oceanology II, The Australian-New Zealand sector, Antarctic Res. Ser., v. 19: Washington (Am. Geophys. Union), p. 234-249.

Woollard, G.P., 1962. Crustal structure in Antarctica: Am. Geophys. Union Mon. 7, p. 53-73. 